\title{
Translational Advances of Hydrofection by Hydrodynamic Injection
}

\author{
Luis Sendra ${ }^{1,2} \mathbb{E}^{\mathbb{D}}$, María José Herrero ${ }^{1,2, *}$ and Salvador F. Aliño ${ }^{1,2,3}$ \\ 1 Pharmacology Department, Faculty of Medicine, Universidad Valencia, Av. Blasco Ibáñez 15, \\ 46010 Valencia, Spain; luis.sendra@uv.es (L.S.); alino@uv.es (S.F.A.) \\ 2 Pharmacogenetics Unit, Instituto de Investigación Sanitaria La Fe, Av. Fernando Abril Martorell 106, \\ 46026 Valencia, Spain \\ 3 Clinical Pharmacology Unit, Área Clínica del Medicamento, Hospital La Fe, Av. Fernando Abril Martorell 106, \\ 46026 Valencia, Spain \\ * Correspondence: maria.jose.herrero@uv.es
}

Received: 2 January 2018; Accepted: 21 February 2018; Published: 1 March 2018

\begin{abstract}
Hydrodynamic gene delivery has proven to be a safe and efficient procedure for gene transfer, able to mediate, in murine model, therapeutic levels of proteins encoded by the transfected gene. In different disease models and targeting distinct organs, it has been demonstrated to revert the pathologic symptoms and signs. The therapeutic potential of hydrofection led different groups to work on the clinical translation of the procedure. In order to prevent the hemodynamic side effects derived from the rapid injection of a large volume, the conditions had to be moderated to make them compatible with its use in mid-size animal models such as rat, hamster and rabbit and large animals as dog, pig and primates. Despite the different approaches performed to adapt the conditions of gene delivery, the results obtained in any of these mid-size and large animals have been poorer than those obtained in murine model. Among these different strategies to reduce the volume employed, the most effective one has been to exclude the vasculature of the target organ and inject the solution directly. This procedure has permitted, by catheterization and surgical procedures in large animals, achieving protein expression levels in tissue close to those achieved in gold standard models. These promising results and the possibility of employing these strategies to transfer gene constructs able to edit genes, such as CRISPR, have renewed the clinical interest of this procedure of gene transfer. In order to translate the hydrodynamic gene delivery to human use, it is demanding the standardization of the procedure conditions and the molecular parameters of evaluation in order to be able to compare the results and establish a homogeneous manner of expressing the data obtained, as 'classic' drugs.
\end{abstract}

Keywords: hydrodynamic; gene therapy; non-viral; translational

\section{Introduction}

The main goal of gene therapy is to use nucleic acids as drugs to treat a wide range of both inherited and acquired diseases. Nucleic acids are large anionic molecules that have great difficulties crossing membrane barriers and usually require the use of vectors or carriers in order to ensure effective transport. Likewise, nucleic acids are easily degraded within biological fluids and this enormously limits their half-life and cell availability. Nowadays, two different types of vectors are being employed to circumvent this situation: viral vectors [1] and non-viral vectors (which are safer but usually less effective).

Since safety is always a priority concern with all drugs destined for human use, it must be underscored that the negative effects associated with these vectors are related to the viral or bacterial sequences that accompany the therapeutic nucleic acids and the carriers (such as proteins or polymers) required to protect them and facilitate their intracellular access. 
Although side effects of viral systems are more relevant than in non-viral systems, both types of vectors show toxicity to some degree. In this sense, the hydrodynamic delivery procedure, based on the rapid/pressurized injection of a large volume of gene solution, represents a great breakthrough in the safe management of gene therapy, since it permits the efficient delivery of nucleic acids into the cell without the use of carriers (i.e., avoiding potential toxicity events derived from carriers or vectors). The hydrodynamic procedure has gained renewed interest derived from its potential use in CRISPR/Cas9 gene constructs for gene edition purposes, or in previously formed complexes for transfer to target organs. The procedure would allow access to the cell nucleus, facilitating the interaction of the RNA guide with the complementary sequence and circumscribing CRISPR effects to the target organ alone-thereby partially avoiding the possible systemic effects.

Unfortunately, this successful procedure first developed in murine models is accompanied by important hemodynamic changes in the animal that make it incompatible with clinical practice. This special circumstance makes adaptation of the procedure in large animals a priority for its clinical translation. Overcoming this limitation would be a great advance in allowing the hydrodynamic procedure to be successfully applied to the clinical setting. In the present work, we describe (from our perspective) the efforts made in this field, with the aim of adapting the procedure to achieve therapeutic results, employing suitable experimental conditions for clinical practice.

\section{Hydrodynamic Model}

During the last decade of the 20th century, different strategies to transfer human genes to mouse hepatocytes in vivo were developed [1], employing both viral and non-viral vectors. Regarding the latter, the viability of the delivery of genes encapsulated in small unilamellar liposomes [1] capable of accessing the hepatocytes was evaluated. The expression of the human alpha-1-antitrypsin $(A A T)$ gene was significantly extended when transfection was associated with partial hepatectomy [2] and was improved and prolonged (approximately $50 \mathrm{ng} / \mathrm{mL}$ ) by employing liposomes encapsulating nuclear location sequences targeted to specific liver cell receptors [3]. However, the final efficacy achieved was several orders of magnitude lower than the values expected to mediate therapeutic benefits. Fortunately, naked DNA transfection employing the hydrodynamic procedure through the mouse tail vein afforded promising results [4]. Later, in 2003, stationary therapeutic plasma levels of protein $(>1 \mathrm{mg} / \mathrm{mL})$ during long periods [5] were achieved. The results obtained showed that this new procedure employing naked DNA achieved higher (more than 4 orders of magnitude or 10,000-fold) efficacy than another approach employing non-viral carrier strategies and evidenced that viral and non-viral systems may achieve equivalent therapeutic efficacies. For these reasons, knowing the hydrodynamic procedure and identifying the mechanisms of gene delivery and the corresponding molecular response are of enormous interest in facilitating clinical translation of the method in a precise, safe and efficient manner. In this chapter, the procedure of hydrodynamic injection, its discovery and development and the underlying mechanism of gene delivery are described.

\subsection{Hydrodynamic Injection of Naked Nucleic Acids}

Preliminary studies employing naked DNA evidenced that when using specific conditions for intravascular injection, nucleic acids can be effectively transfected in vivo without any carrier or vector, since:

(a) The DNA reached the muscle and was expressed [6].

(b) The mouse liver could be transfected in vivo by the pressurized injection of a hyperosmotic solution containing naked human growth hormone (hGH) DNA through the portal vein [7], achieving plasma protein levels (65 ng/mL) 50-fold higher than the normal basal values.

(c) High expression levels of tracer genes were achieved in the hind limb muscle of rats by pressurized DNA injection through the iliac artery [8].

The "hydrodynamic procedure" (Figure 1) was definitely described in 1999 [9] as the rapid injection (5-7 s) of a large saline solution volume (1/10 body weight) containing naked DNA through the mouse tail 
vein. In a typical experiment employing a mouse of $20 \mathrm{~g}$ body weight, $2 \mathrm{~mL}$ of saline DNA $(0.5-5 \mathrm{mg} / \mathrm{kg})$ solution is injected in $5 \mathrm{~s}$. The procedure is especially effective for liver gene transfer [10-12] but also for transfer to other organs such as kidney [13], skeletal muscle [14,15] and cardiovascular tissue [16]. After hydrodynamic injection, a rapid increase in plasma levels of liver enzymes AST and ALT is observed, which is quickly normalized within one to three days. On the other hand, the animals tolerate the administration of multiple doses, without apparently affecting liver function or causing any other metabolic effects and/or injuries in other organs [9,14].

The main limitation of the procedure arises from the hemodynamic changes induced by hydrodynamic injection. In the mouse, the rapid injection of $2 \mathrm{~mL}$ of saline solution doubles its volemia and consequently results in cardiac pump failure due to the sudden increase in preload.

The hemodynamic impact of injection is important. However, although the animals suffer immediate collapse due to transient cardiac overload, they rapidly recover within the first $5 \mathrm{~min}$. This is due to rapid normalization of cardiac preload, which is possible thanks to the high heart rate of mice. However, these hemodynamic changes would not be compatible with human use and represent the first and main limiting step that must be circumvented in order to allow clinical translation of the hydrodynamic procedure.

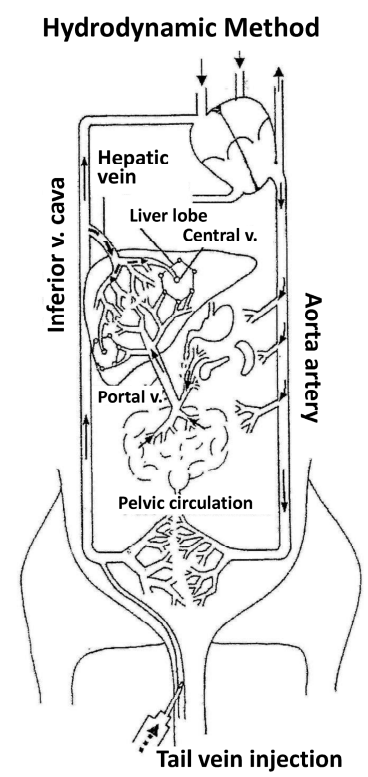

Figure 1. Hydrodynamic method. The figure shows the mouse normal blood flow and the effects mediated by hydrodynamic injection (indicated by a gap line within tail vein and from inferior vena cava to the liver through hepatic vein). Blood flows from tail vein to heart, who drives it to lungs to be oxygenated, returned to heart and distributed to the entire whole through aortic artery. The liver receives a profuse blood supply from the hepatic artery and portal vein. Blood flow from portal vein to inferior cava vein must cross the liver parenchyma through the hepatic sinusoids. When hydrodynamic injection is performed through tail vein, this large volume $(2 \mathrm{~mL})$ drains into inferior cava vein, it results in increased venous pressure that mediates retrograde blood flow into liver sinusoids (arrow with dashed line). This permits the gene accessing the liver. Employing different experimental strategies, the hydrofection mechanism has been suggested to involve transient inversion of intrahepatic blood flow and massive fluid endocytic vesicles in hepatocytes, mainly in those distributed around the central vein. The volume stays immobilized but pulsatile until heart, thanks to heart rate increasing, pumps this volume to bloodstream.

\subsection{Delivery Mechanism}

The mechanism underlying the hydrodynamic transfection (hydrofection) of genes in the murine model [10-12] has not been elucidated to date. Knowledge of this mechanism will contribute to better understand and adapt the procedure to large animals under conditions compatible with clinical use. 
Since the mechanism must be common in all regions, except in relation to some organ particularities (e.g. resilience, vascularization, size, type of vascular endothelium, etc.) that define the injection conditions (volume, flow rate, DNA concentration, etc.) in each case, the present review focuses on the advances achieved in liver gene transfer. It must be underscored that although the experimental stages and results have been clearly confirmed, correct interpretation of the entire process has not yet been corroborated.

The main findings to date in relation to the hydrofection mechanism are described below:

(1) The first experiments employing tracer genes and immunohistochemical methods to identify the liver expression of exogenous genes showed expression to be mainly located in central vein areas, thereby supporting that the inversion of flow sense mediates retrograde backflow to the liver and this could be involved in the mechanism of action (Figure 1).

(2) Hydrodynamic injection mediates a remarkable pressure increase in the cava vein, since the tail vein is its direct tributary. This is due to the fact that the administration of a large volume $(2 \mathrm{~mL}$ in the mouse) in this area (cardiac preload) means doubling the volemia-thereby generating an important pressure increase. This process inverts the pressures at cava vein level with respect to the portal vein and causes retrograde backflow of blood to the liver. This idea is supported by experimental data. The simultaneous measurement of pressures in portal and cava vein areas shows that inversion of portal versus cava pressures exists both during injection and at least 5 min later.

(3) Flow inversion has been observed by intravital microscopy [17] during hydrodynamic injection and minutes later. During rapid injection, flow is inverted and remains static but pulsatile during the first minute. Anterograde flow recovers slowly and progressively until normalization is reached within 5 or 6 min after hydrodynamic injection. It is assumed that the transfection process occurs during this short period of time.

(4) Ultrastructural morphological changes [17] in liver tissue during hydrodynamic injection evidence that the hydrodynamic force exerted upon the liver sinusoids promotes vascular distension, widening sinusoidal pore diameter and the endothelial junctions and facilitating access of the DNA solution to the likewise widened virtual Disse space (Figure 2). This process allows interaction of the aqueous solution with hepatocytes in a high-pressure scenario that promotes the formation of multiple endocytic vesicles without solution of continuity of the cell membrane, as observed by electron microscopy. This excludes the possibility of DNA access to the hepatocyte through membrane disruption and the formation of large permissive pores instead of endocytic vesicles. Moreover, large pores could compromise hepatocyte viability. It must be underscored that the existence of narrow junctions (tight junctions) among hepatocytes limits free DNA diffusion through the intercellular spaces. Thus, hepatocyte hydrofection (gene transfer mediated by hydric forces) could be due to DNA saline solution entry into the hepatocyte, which is mediated by the hydrodynamic force exerted.

(5) Although the possibility that part of the DNA may access the hepatocyte through a receptormediated process [7] cannot be discarded, this process would contribute only slightly to the efficiency of hydrodynamic delivery.

(6) The early experimental data, employing molecules of different size and weight, as well as recent observations employing colloidal gold nanoparticles of known diameter and electron microscopy [18,19], support the idea that hydrofection implies a passive process without energy consumption but driven by hydrodynamic force through more permissive sites of the cell membrane, including endocytic vesicles. The dimension of the membrane sinusoids, depending on the species, can be as much as $100 \mathrm{~nm}$ in diameter [20]. However, only particles with diameters smaller than $10 \mathrm{~nm}$ can access the cell [21], whereas larger particles are virtually refractory to hepatocyte entry but can be observed within the cytoplasm of phagocytic cells (Kupffer cells). This interpretation of the delivery mechanism combines DNA access to the hepatocyte through the cell membrane with no important liver toxicity and justifies the acute plasma increase in transaminases due to marginal cell destruction, which is rapidly reverted within the first days after hydrodynamic injection. This suggests that injured cells are eliminated, whereas the efficiency of transfection remains in those cells in which DNA has 
gained access in a less aggressive manner. Nevertheless, further studies are needed to establish the exact mechanism of gene delivery mediated by the hydrodynamic procedure.

\section{Hydrofection Procedure}

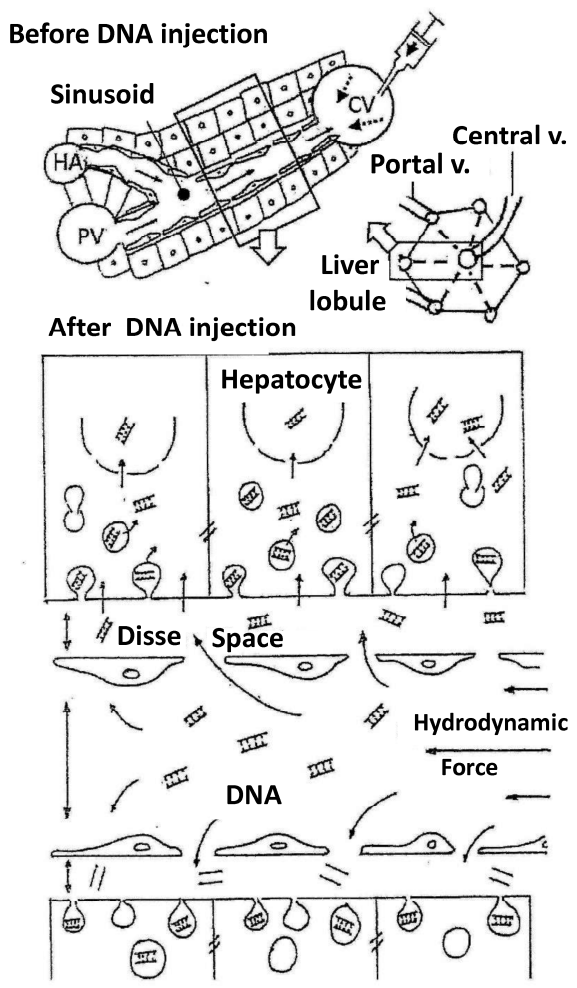

Figure 2. Hydrofection mechanism. The figure shows the mechanism underlying the hydrofection gene transfer to the cells in liver. Upper panel shows a liver lobe unit (right) with its vascular system, which has been enlarged (left) to show the sinusoid vessel detail. Squared area is augmented in lower panel, where the sinusoid vessel organization is showed in detail just after hydrofection. It can be observed that retrovenous injection mediates hydrodynamic force that widens the vessel and virtual Disse space, separates endothelial cells and induces large number of endocytic vesicles on hepatocytes without obvious plasma membrane rupture It suggests that hydrodynamic force mediates DNA delivery to hepatocyte via diffusion process, involving a microfluid uptake process and/or penetration through facilitated permeable sites in the cell membrane. PV: portal vein; CV: Cava vein; HA: hepatic artery.

\section{Gene Transfer Applications}

Gene therapy offers the possibility of treating any type of disease whose aetiology is well defined at molecular level. Once the cause of an illness is known, it is possible to specifically design a gene construct with the ability to improve the pathological scenario and then transfer it with availability for being transcribed and translated. Among the different procedures proposed, hydrodynamic gene transfer in the mouse has been shown to be efficient for transferring genes to different organs in a safe manner and in some cases with high efficacy. This fact makes it possible to expand the potential therapeutic applications of the technique. In this regard, the hydrodynamic procedure for gene transfer has been widely applied for treating a range of diseases in different mouse organs such as muscle and liver. Next, different applications for a wide range of both acquired and inherited diseases are described.

\subsection{Muscle}

The most widely employed procedures for gene transfer to muscle were the direct intramuscular injection and vascular injection of gene constructs through the hind limb vein. 
Muscular tissue has served as a target of this therapy since its implantation. Zhang et al. [22] injected a DNA plasmid with the entire murine dystrophin gene into the skeletal muscles of the hind limbs of the Duchenne mouse model. These authors achieved $18-20 \%$ of the normal levels of dystrophin protein with 11-16\% expressing myofibres. Zhang et al. [23] in turn injected a plasmid encoding siRNA to silence nicotinic acetylcholine receptor $\alpha 1$ to heart and 78\% knockdown was achieved 16 weeks after transfection. Bostrom et al. [24] transferred peroxisome proliferator-activated receptor-gamma coactivator-1alpha ( $P G C 1 \alpha)$ gene to skeletal muscle and reported protein expression, which improved obesity and glucose metabolism. As a proof of concept, Guess et al. (2013) [25] injected a plasmid encoding tracer siRNA to study the distribution of hind limb gene delivery and observed disperse expression across multiple hind limb muscle groups. Mukumoto et al. [26] compared hydrodynamic liver and intramuscular gene delivery procedures and the mice receiving intramuscular injections yielded better results than mice receiving hydrodynamic injections. Nagata et al. [27] transferred insulin-like growth factor (IGF-1) carried in a polyplex nanomicelle through hydrodynamic hind limb injection in mice with sciatic nerve injury and reported improved motor function for at least 25 days.

\subsection{Liver}

Given the efficiency of hydrodynamic injection in transferring genes to the liver, this was the most widely employed strategy. Different modifications seeking to enhance its efficacy were partial hepatectomy, integrative plasmids and the use of targeting.

One of the most extensively studied disorders with a potential for treatment with non-viral gene therapy and for which the hydrodynamic procedure has shown the most promising outcomes is probably hAAT deficiency [28]. The entire human $h A A T$ gene encapsulated in liposomes of different diameters was transferred to mice. Small liposomes (54 $\pm 11 \mathrm{~nm}$ in diameter) carried the gene to parenchymal cells, mediating the presence of protein in plasma seven days after treatment. Subsequently, Aliño et al. [1,29] reported hAAT protein expression in liver over two weeks, achieving plasma concentrations of up to $160 \mathrm{ng} / \mathrm{mL}$ after single-dosing plus liver regeneration induced by partial hepatectomy. Additional studies [2] reported anionic liposomes to mediate more durable protein expression, reaching plasma levels of over $100 \mathrm{ng} / \mathrm{mL}$ for more than five months. In 2000, Zhang et al. [4] employed the hydrodynamic procedure $[9,30]$ to transfer the $h A A T$ gene and reported the plasma expression of $2-5 \mu \mathrm{g} / \mathrm{mL}$ of protein for six months with peak levels of $0.5 \mathrm{mg} / \mathrm{mL}$. In 2001, Dasi et al. [3] injected $h A A T$ gene encapsulated within asialofetuin liver-targeted liposomes, reporting stationary plasma levels of approximately $50 \mathrm{ng} / \mathrm{mL}$ of hAAT protein during more than 12 months. The same group [5] transferred the entire genomic $h A A T$ gene driven by its natural promoter and reported long-term ( $>6$ months) therapeutic plasma levels $(>1 \mathrm{mg} / \mathrm{mL})$ of human protein in mice. Immunohistochemical studies revealed that no more than $5-10 \%$ of the liver cells were producing the exogenous protein. Furthermore, it was observed that the injection widened the Disse space and induced the formation of massive endocytic vesicles within the hepatocytes that could facilitate DNA access into the cells. Hydrofection was not only shown to be efficient for $h A A T$ gene transfer in mice but also safe [31]—without significantly modifying the levels of liver enzymes or the expression of other genes.

Haemophilia is another ideal candidate for successful treatment via hydrodynamic gene transfer, since it is an inherited monogenic disease with the liver as specific target organ for gene therapy. Schuttrumpf et al. [32] used human coagulation factor IX in knockout (KO) mice and achieved a plasma expression of $100 \%$ normal levels of fully functional FIX protein. In 2009, Keravala et al. [33] transferred phiC31 integrase and the hFIX gene to FIX knockout mice. They reported therapeutic plasma levels of protein over six months and functional activity in the correction of bleeding after tail clipping. Likewise, in 2011, Kim et al. [34] reported long-term expression of hFIX (above $500 \mathrm{ng} / \mathrm{mL}$ ) and clotting activity for seven months in FIX knockout mice after hydrodynamic injection without genome integration. Given the positive outcomes obtained, researchers evaluated gene constructions with greater potential to be employed in humans. In this sense, Schuttrumpf et al. [35] compared the 
efficacy of transgene expression of classic plasmids versus minicircle vectors in FIX knockout mice over time. Both systems mediated therapeutic plasma levels, with minicircles reaching longer-lasting expression. Having demonstrated the potential application of hydrofection to treat haemophilia B, Matsui et al. [36] employed this strategy to test its possible use in haemophilia A. Accordingly, these authors transferred the entire human FVIII cDNA in a piggyback transposon to mice and reported protein plasma expression $(40 \mathrm{mU} / \mathrm{mL})$ for more than 300 days, with functional activity in FVIII knockout mice.

The metabolic disorders diabetes, cholesterolemia and obesity have been the subject of hydrofection studies conducted to evaluate potential applications of the technique to these diseases. In this sense, Holm et al. [37] transferred Short-Chain AcylCoA Dehydrogenase Deficiency (SCAD) cDNA to SCAD knockout mice and reported 30\% of SCAD normal levels during 31 days. Another metabolic disease that has been evaluated for treatment using the hydrodynamic procedure is familial hypercholesterolemia. Turunen et al. [38] injected sleeping beauty transposons carrying LDLR and VLDLR to LDLR-deficient mice and observed initial reductions in plasma cholesterol of $17-19 \%$, with significant stabilization of cholesterol levels during at least 6.5 months. Jiang et al. [39] hydrofected leptin and Ciliary Neurotrophic Factor (CNTF) genes in mice to evaluate their role in preventing obesity and observed significant reductions in food intake and weight. Mukumoto et al. [26] in turn evaluated the effect of the hydrodynamic and intramuscular injection of a plasmid encoding IL-6 gene upon diet-induced obese mice. These authors observed lower weight and fat accumulation in treated mice, lesser weight gain and reduced mRNA expression of metabolism-related genes. González-Muniesa et al. [40] hydrofected a plasmid encoding the UCP-1 gene-a mitochondrial protein with the ability to uncouple mitochondrial respiration - and reported that this strategy can mediate the expression of exogenous genes within the liver mitochondrion, opening a wide range of applications. As an approach to explore the potential application of hydrofection to treat type 1 diabetes, He et al. [41] used insulin cDNA in a plasmid and as a sleeping beauty transposon in diabetic mice and reported the expression of insulin in both plasma and liver tissue, as well as blood glucose reduction and weight loss control. Fukushima et al. [42] transferred the adiponectin gene, which is involved in glucose and lipid metabolism and observed a decrease in circulating glucose (due to the elevated glucose uptake) and triglycerides. Gao et al. [10] also studied the potential use of hydrodynamic gene transfer to treat and/or prevent obesity. Mice fed a high fat diet were treated with mIL10 gene, whose overexpression prevented weight gain and glucose intolerance. Ma et al. [43] employed a similar model to transfer adiponectin and/or its receptor 2 gene into skeletal muscle and liver and reported similar results - with intramuscular injection yielding slightly better outcomes. Vakili et al. [44] studied the potential benefit of the hydrodynamic procedure for treating type 2 diabetes in diabetic mice. They transferred small hairpin RNA (shRNA) to silence the overexpression of protein tyrosine phosphatase 1B (PTP1B), present in diabetes. The expression of PTP1B decreased by $84 \%$ and the plasma glucose levels also diminished. Hydrodynamic injection in experimental diabetic mice has also been used as a screening test to identify therapeutic targets [45]. Gao et al. [11] transferred FGF21 cDNA and evaluated its effect on mice fed a high fat diet-reporting reduced obesity and body weight gain and the alleviation of liver steatosis. In a similar way, Ma et al. [12] injected the IL-6 gene to high fat diet obese mice in order to evaluate its potential role in the treatment of obesity, observing increased expression of lipolysis genes, a reduction of body weight and improved obesity-associated steatosis.

\subsection{Other Inherited Diseases}

Monogenic inherited diseases are perfect target diseases for gene therapy, since treatment consists of repairing the mutated gene and/or implementing the correct gene to restore the normal phenotype. One of these disorders is mucopolysaccharidosis (MPS), which comprises a group of conditions caused by malfunctioning of lysosomal storage. Camassola et al. [46] injected $\alpha$-L-idurodinase (IDUA) enzyme cDNA in a model of MPS I mouse and reported efficient transgene expression, which reduced the levels of accumulated glycosaminoglycans (GAGs). In a similar way, Richard et al. [47] transferred the $\beta$-glucuronidase gene through hydrodynamic injection or intramuscular injection to treat MPS VII and 
reported a reduced accumulation of GAGs. In turn, in 2014, Quiviger et al. [48] injected N-sulfoglucosamine sulfohydrolase (SGSH) cDNA in a model of MPS IIIA mouse and observed high serum levels of protein, with the correction of GAG accumulation. Von Willebrand disease (VW) is another inherited disease studied as a target for hydrodynamic gene therapy. Pergolizzi et al. [49] used murine VWF cDNA and achieved the normalization of bleeding time $48 \mathrm{~h}$ after gene delivery in mice. Sickle-cell disease (SCD) has also been evaluated as a therapeutic target for hydrodynamic gene transfer. Belcher et al. [50] transferred a sleeping beauty transposon carrying the wild type rat Hmox-1 gene in SCD mice, which presented hypoxia-induced stasis inhibition. Phenylketonuria (PKU) is a monogenic disease of hepatic origin defined by phenylalanine hydroxylase (PAH) deficiency. Viecelli et al. [51] and Grisch-Chan et al. [52] injected a minicircle encoding PAH cDNA to PKU mice and achieved normalized blood phenylalanine for more than one year. Such long-term expression was suggested to be due to the persistence of minicircles within hepatocytes (probably but not confirmed, as episomes).

\subsection{Infectious Diseases}

The liver can be affected by other acquired and potentially life-threatening disorders. One of the most important is hepatitis, which can have several causes, such as inflammatory alterations, viral infection or a fulminant process characterized by liver inflammation and autoimmune responses. The hydrofection procedure has been employed to create models of hepatitis $B(\mathrm{HBV})$ and hepatitis $\mathrm{C}(\mathrm{HCV})$ in mice, making it possible to study the pathology and immune response. In this regard, Yang et al. [53] administered a sleeping beauty transposon carrying the HBV genome and evaluated its expression and the response of the immune system against it. In addition, a model of hepatitis $C$ was developed by McCaffrey et al. [54], injecting HCV genomic RNA. Kim et al. [55] transferred HCV-core-specific siRNA to mice with HCV to limit viral gene expression, silencing viral expression $65-75 \%$ two days after injection. Viral infections (hepatitis viruses, adenoviruses) and other causes such as toxins, can produce liver failure. In these cases, the most important concern is to protect hepatocytes from apoptosis. With this purpose, Zender et al. [56] injected siRNAs to silence Cas8, which plays an important role in cell apoptosis and reported one-month survival of mice when treated with anti-apoptosis siRNA versus one day survival in the case of the untreated controls. Fulminant hepatitis and liver inflammation have been studied for gene therapy treatment and researchers have proposed different strategies. In this respect, osteopontin (OPN) has been suggested to increase in fulminant hepatitis and Saito et al. [57] evaluated the benefit of silencing the mentioned gene by injecting anti-OPN siRNA, resulting in amelioration of liver tissue injury. Xu et al. [58] in turn observed that the ectopic expression of B7-H4-Ig fusion protein mediated by hydrodynamic transfer could suppress liver necrosis in mice with induced hepatitis. In a model of hepatitis, Bulau et al. [59] transferred the IL-37 gene and observed significant reductions in the expression of proinflammatory genes (IL-1, IL-6 and others). Shashidharamurthy et al. [60] showed the hydrodynamic delivery of human Fc $\gamma$ R-Ig dimers to block immune-complex mediated inflammation in mice. Anavi et al. [61] employed a model of induced liver inflammation mediated by the impairment of hypoxia-inducible factor 1 (HIF-1). Transfer of HIF-1 gene to these iNOS knockout mice permitted its expression in liver, ameliorating the liver damage. The NK2GD receptor is another factor related to the initiation and maintenance of liver inflammation. In this regard, Huang et al. [62] employed three specific short hairpin RNAs to silence three major ligands of NKG2D on hepatocytes, achieving the downregulation of those ligands that alleviated fulminant hepatitis. Another strategy applicable in liver inflammation consists of silencing proinflammatory cytokines such as IL-6. In this sense, Gortz [63] injected cDNA encoding a receptor fusion protein to inhibit IL-6 that allowed blocking of the acute phase of liver inflammation. Once the inflammatory process has been stopped and even reverted, liver tissue repair could be necessary. This was explored by Tsai et al. [64], who demonstrated that the overexpression of fibroblast growth factor 7 (FGF7) mediated by hydrofection could notably promote liver cell proliferation after partial hepatectomy.

Although the aforementioned diseases have been the conditions most widely studied for treatment through hydrodynamic gene transfer, they are not the only ones. In effect, researchers have evaluated potential application of the procedure to many other different inherited and acquired diseases. 


\subsection{Cancer}

One of the major acquired disorders investigated for potential treatment using hydrodynamic gene transfer is cancer. Different approaches have already been adopted. Wu et al. [65] designed a gene construct carrying a member of the TNF family with the capacity to induce apoptosis in specific human tumours. Its transfer in SCID mice with human breast tumours resulted in tumour regression and reduced growth compared to the controls. Yazawa et al. [66] transferred the foetal liver kinase 1 (Flk-1) gene, a receptor of vascular endothelial growth factor (VEGF), aiming to block tumour angiogenesis. This permitted a decrease in the formation of new vessels and suppression of the growth of pre-existing tumours. Another strategy involved use of the interferon gamma gene, with the ability to inhibit the formation of metastases. Following this strategy, Miyakawa et al. [67] injected a plasmid encoding a fusion protein formed by IFN- $\gamma$ and serum albumin and this permitted prolongation of the serum half-life of the protein. Ando et al. [68] confirmed these results and demonstrated that a reduced number of $\mathrm{CpG}$ motifs in gene constructs resulted in more durable transgene expression. In 2013, Miyakawa et al. [69] designed another plasmid encoding a fusion protein containing IFN- $\gamma$ and albumin binding protein that could extend the circulating half-life of IFN, retaining 40-50\% of biological activity. With the aim of avoiding the systemic side effects related with IFN, Ando et al. [70] designed constructions encoding fusion proteins of IFN and heparin binding domain in order to target the liver. With this strategy, they achieved tumour growth suppression without systemic adverse effects. Given the interest of immunotherapy strategies against cancer, Ochoa et al. [71] constructed an expression plasmid encoding IL15 and Apo A1 and co-administered it with a plasmid carrying the sushi domain of IL15R $\alpha$. These authors achieved an increase in NK cell count, as also reported by Barao et al. [72] and an increase in the number of memory CD8 lymphocytes in blood, spleen and liver-with modest therapeutic effects against colon cancer, for 60 days. Sun et al. [73] evaluated the antitumor activity of IL15/sIL15R $\alpha$ upon Lewis lung tumour growth in lungs, liver and kidney. They transferred this gene as DNA plasmid, reporting inhibition of tumour growth in all three organs and prolonged survival time. Qiu et al. [74] in turn injected murine IL28B to the liver, aiming to exert its immunomodulatory effect in lungs. This strategy resulted in a decreased expression of inflammatory proteins in mice exposed to cigarette smoke for 21 days.

\subsection{Other Acquired Diseases}

Many other disorders are potentially amenable to treatment with hydrodynamic gene therapy. For instance, Sondergaard et al. [75] employed a hypophysectomised mouse model to transfer the human growth hormone gene. This strategy mediated the normalization of tibia and tail length and body weight gain at the end of the experiment. Lee et al. [76] demonstrated long-term and robust parathyroid hormone expression after transferring a PTH cDNA plasmid containing the OC31 integrase, with transgene integration within the genome. Okumura et al. [77] proved the efficacy of the chemotaxin 2 (LECT2) gene in treating osteoarthritis in knockout mice with induced osteoarthritis. Dermatitis has also been evaluated for the application of hydrodynamic gene transfer. Watcharanurak et al. [78] transferred the murine IFN- $\gamma$ gene to mice with early dermatitis and achieved the expression of Treg immunomodulatory cytokines, with improvement of the clinical symptoms. Different types of infection have also been treated with hydrodynamic gene transfer. Wesche-Soldato et al. [79] employed septic mice to transfer siRNA against Fas or caspase- 8 and recorded decreased mRNA expression and significantly improved survival. Similarly, Tompkins et al. [80] designed genic constructs to block highly conserved regions of the influenza A virus and inhibit its replication. The treatment of bacterial infections by gene therapy has also been evaluated. Lu et al. [81] reported reduced local skin bacterial counts after human kallistatin transfection in mice previously infected with group A Streptococcus.

Given the promising results of the hydrodynamic procedure, other organs and tissues such as the kidneys [82] were studied in Fabry mice. The applications of hydrodynamic gene therapy in small animals are summarized in Table 1. 
Table 1. Hydrodynamic gene transfer works performed in murine model. The table shows the author of each work, the publication year, the target organ assayed, gene and gene construction, conditions of hydrodynamic injection, experimental aim and methodology, disease of interest and effect duration.

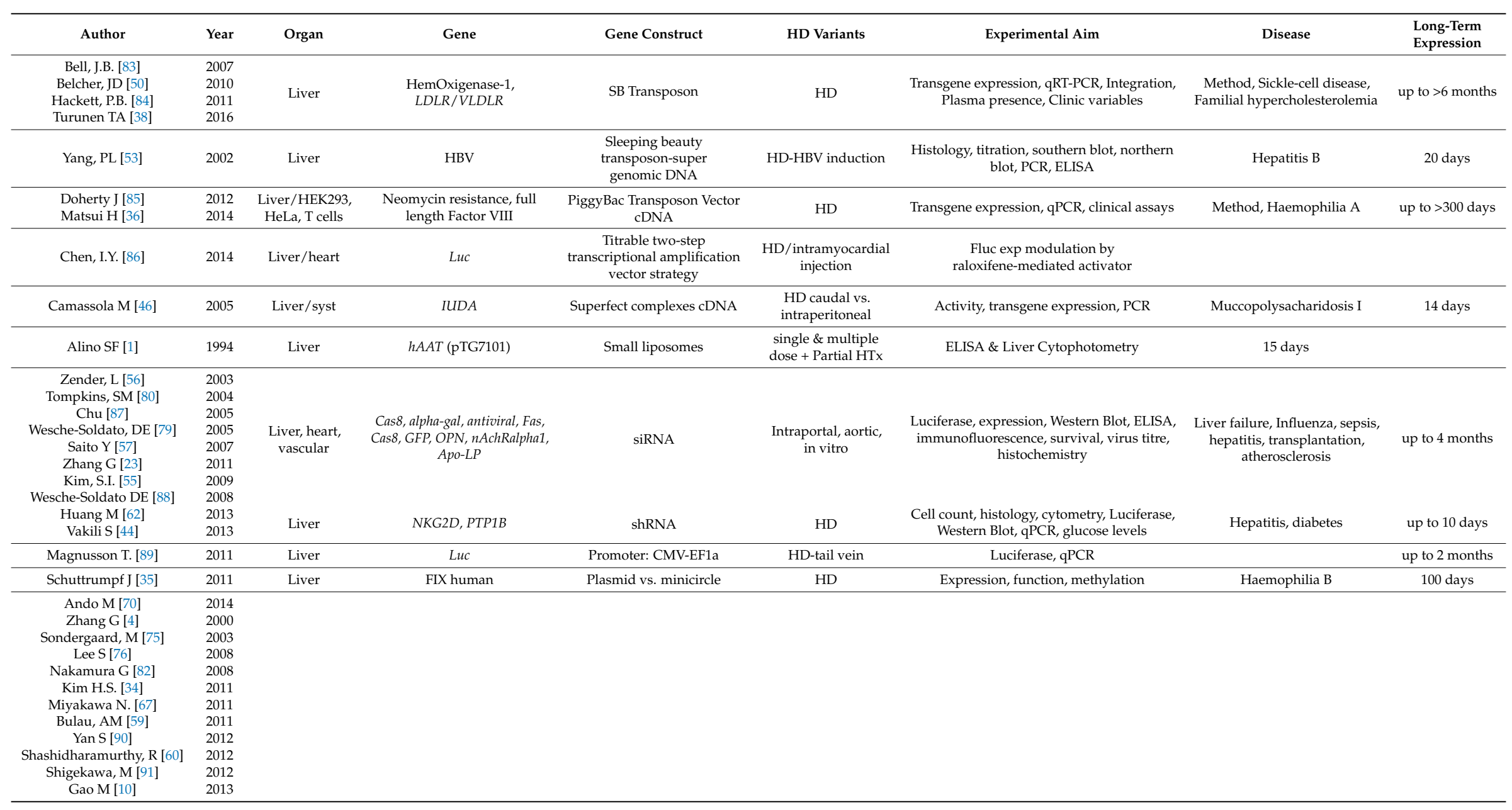


Table 1. Cont

\begin{tabular}{|c|c|c|c|c|c|c|c|c|}
\hline Author & Year & Organ & Gene & Gene Construct & HD Variants & Experimental Aim & Disease & $\begin{array}{l}\text { Long-Term } \\
\text { Expression }\end{array}$ \\
\hline Guess, MG [25] & 2013 & \multirow{22}{*}{$\begin{array}{l}\text { Liver, kidney, } \\
\text { muscle, lung, } \\
\text { cells, tumour }\end{array}$} & \multirow{22}{*}{ 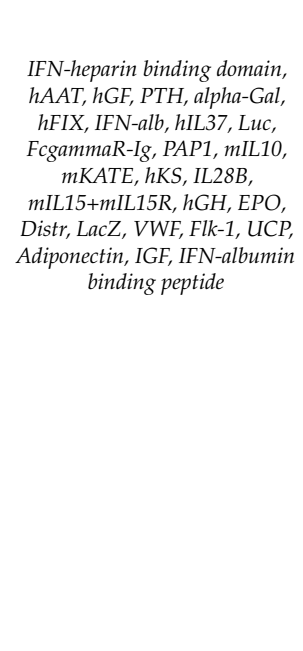 } & \multirow{22}{*}{ Plasmid DNA } & \multirow{22}{*}{$\begin{array}{l}\text { HD, retro-orbital, } \\
\text { hind limb, im, kidney } \\
\text { injection, } \\
\text { saphenous vein }\end{array}$} & \multirow{22}{*}{$\begin{array}{l}\text { Serum concentration, expression, ELISA, } \\
\text { qPCR, Western Blot, histology, Luciferase, } \\
\text { glucose levels, injury, electron microscopy }\end{array}$} & \multirow{22}{*}{$\begin{array}{l}\text { Cancer, hAAT deficiency, } \\
\text { hypophysectomised, } \\
\text { hypoparathyroidism, Fabry } \\
\text { disease, Haemophilia B, } \\
\text { metastasis, hepatitis, } \\
\text { pancreatitis, obesity, dystrophy, } \\
\text { inflammation, hGH deficiency, } \\
\text { streptococcus infection, } \\
\text { method, Von Willebrand } \\
\text { disease, diabetes, nerve injury }\end{array}$} & \multirow{22}{*}{ up to $>8$ months } \\
\hline Lu S.L. [81] & 2013 & & & & & & & \\
\hline Qiu C [74] & 2014 & & & & & & & \\
\hline Sun $\mathrm{H}[73]$ & 2016 & & & & & & & \\
\hline $\begin{array}{c}\text { Wolff, JA [6] } \\
\text { Dagnaes-Hansen. F [92] }\end{array}$ & 1990 & & & & & & & \\
\hline $\begin{array}{l}\text { Dagnaes-Hansen, F [92] } \\
\text { Alino, SF [5] }\end{array}$ & $\begin{array}{l}2002 \\
2003\end{array}$ & & & & & & & \\
\hline Hagstrom, JE [93] & 2004 & & & & & & & \\
\hline Zhang, G. [94] & 2004 & & & & & & & \\
\hline Crespo, A [17] & 2005 & & & & & & & \\
\hline $\begin{array}{l}\text { Pergolizzi, RG [49] } \\
\text { Yazawa H [66] }\end{array}$ & 2006 & & & & & & & \\
\hline $\begin{array}{c}\text { Yazawa, H [66] } \\
\text { Gonzalez-Muniesa, P [40] }\end{array}$ & $\begin{array}{l}2006 \\
2006\end{array}$ & & & & & & & \\
\hline $\begin{array}{l}\text { Gonzalez-Muniesa, P [40] } \\
\text { Fukushima, M [42] }\end{array}$ & 2007 & & & & & & & \\
\hline Li, W. [95] & 2008 & & & & & & & \\
\hline Schuttrumpf, H [32] & 2008 & & & & & & & \\
\hline Suda T [96] & 2008 & & & & & & & \\
\hline Podetz-Pedersen, KM [97] & 2010 & & & & & & & \\
\hline $\mathrm{Xu}, \mathrm{JF} .[58]$ & 2010 & & & & & & & \\
\hline Herrero, M.J. [31] & 2011 & & & & & & & \\
\hline $\mathrm{Ma}, \mathrm{Y}[43]$ & 2013 & & & & & & & \\
\hline Miyakawa, N. [69] & 2013 & & & & & & & \\
\hline Wooddell, C [98] & 2011 & & & & & & & \\
\hline Nagata, K [27] & 2014 & & & & & & & \\
\hline $\mathrm{He}, \mathrm{C}[41]$ & 2004 & \multirow{9}{*}{$\begin{array}{l}\text { Liver/Skeletal } \\
\text { Muscle }\end{array}$} & \multirow{9}{*}{$\begin{array}{l}\text { Insulin, } h G F, I L 6, I F N g, \\
m F G F 21, S G S H, \\
\text { IL6-RFP-Fc, IL6 }\end{array}$} & \multirow{9}{*}{ Plasmid cDNA } & \multirow{9}{*}{$\mathrm{HD}, \mathrm{im}$} & \multirow{9}{*}{$\begin{array}{l}\text { Expression, plasma protein, } \\
\text { immunohistology, clinical analysis, } \\
\text { pathology, qPCR, WB, ELISA }\end{array}$} & \multirow{9}{*}{$\begin{array}{l}\text { Diabetes type } 1 \text { and } 2 \text {, obesity, } \\
\text { glomerulonephritis, dermatitis, } \\
\text { MPSIIIA, inflammation }\end{array}$} & \multirow{9}{*}{ up to 120 days } \\
\hline $\mathrm{Bu}, \mathrm{X}[99]$ & 2011 & & & & & & & \\
\hline Mukumoto, H [26] & 2013 & & & & & & & \\
\hline Watcharanurak, K [78] & 2013 & & & & & & & \\
\hline Baribault, H. [45] & 2014 & & & & & & & \\
\hline Gao, M [11] & 2014 & & & & & & & \\
\hline Quiviger, M [48] & 2014 & & & & & & & \\
\hline Gortz, D [63] & 2015 & & & & & & & \\
\hline $\mathrm{Ma}, \mathrm{Y}[12]$ & 2015 & & & & & & & \\
\hline Duguid, JG [100] & 1998 & \multirow{3}{*}{ Cell lines } & \multirow{3}{*}{$b$-Gal, hGH, eGFP } & \multirow{3}{*}{$\begin{array}{l}\text { Peptide/DNA pH sensitive, } \\
\text { PEI \& DOTAP/ } \\
\text { DNA complexes }\end{array}$} & \multirow{3}{*}{ in vitro } & $\begin{array}{l}\text { Cytochemistry, g-gal chemoluminiscence, } \\
\text { fluorimetry, electrofluorescence TEM }\end{array}$ & & \multirow{3}{*}{14 days } \\
\hline Moret, I [101] & 2001 & & & & & cytofluorescence, dynamics of gene transfer & & \\
\hline Alino, SF [102] & 2000 & & & & & PD:D-R, Em, EC50, Pot, Afin & & \\
\hline Alino, SF [28] & 1993 & \multirow{3}{*}{ Liver } & \multirow{3}{*}{$h A A T$} & \multirow{3}{*}{$\begin{array}{l}\text { Large/small liposomes, } \\
\text { Liposomes (-)vs(+) plus }\end{array}$} & \multirow{3}{*}{ iv, HTx } & \multirow{3}{*}{$\begin{array}{l}\text { Cytophotometry, DNA, } \\
\text { Size Distribution, ELISA }\end{array}$} & & \multirow{3}{*}{ up to 5 months } \\
\hline Alino, SF [5] & 1993 & & & & & & & \\
\hline $\begin{array}{l}\text { Alino, SF [29] } \\
\text { Crespo, J [2] }\end{array}$ & 1996 & & & & & & & \\
\hline Budker, V [7] & 1996 & Liver & $b$-Gal, $h G H$ & Naked & $\begin{array}{l}\text { DNA, hypertonic } \\
\text { solution-portal } \\
\text { injection, hepatic } \\
\text { vein occlusion }\end{array}$ & ELISA \& histology & & 2 days \\
\hline
\end{tabular}


Table 1. Cont

\begin{tabular}{|c|c|c|c|c|c|c|c|c|}
\hline Author & Year & Organ & Gene & Gene Construct & HD Variants & Experimental Aim & Disease & $\begin{array}{l}\text { Long-Term } \\
\text { Expression }\end{array}$ \\
\hline $\begin{array}{c}\text { Xu, Z.X. [103] } \\
\text { Keravala, A. [33] }\end{array}$ & $\begin{array}{l}2009 \\
2011\end{array}$ & Liver & $h F I X, h A A T$ & Integrative DNA plasmid & $\mathrm{HD}$ & $\begin{array}{l}\text { Specific insertion, plasma concentration, } \\
\text { toxicity, expression, IHC }\end{array}$ & Haemophilia B & up to 250 days \\
\hline Ando, M [68] & 2012 & Liver & IFN & $\begin{array}{l}\text { pDNA varying } \mathrm{CpG} \\
\text { motifs number }\end{array}$ & $\mathrm{HD}$ & Expression & Cancer & \\
\hline Viecelli HM [51] & 2014 & Liver & $m P A H$ & Minicircular cDNA & $\mathrm{HD}$ & $\begin{array}{l}\text { Expression serum and tissue, } \\
\text { qPCR, histology }\end{array}$ & Phenylketonuria & $>1$ year \\
\hline McCaffrey, AP [54] & 2002 & Liver & $\mathrm{HCV}$, others & $\begin{array}{l}\text { Genomic RNA-HCV internal } \\
\text { ribosome entry site firefly } \\
\text { luciferase, Non-viral }\end{array}$ & HD-HCV model & Histology, Luciferase & Hepatitis C & 10 days \\
\hline $\begin{array}{l}\text { Habbitt, OC [104] } \\
\text { Okumura, A [77] }\end{array}$ & $\begin{array}{l}2007 \\
2008\end{array}$ & $\begin{array}{l}\text { Liver } \\
\text { Liver }\end{array}$ & $\begin{array}{c}\text { gDNA }(100 \mathrm{~kb}), e G F P, L D L R \\
L E C T 2\end{array}$ & $\begin{array}{l}\text { gDNA, GenomicGenes, BAC } \\
\text { Expression vector non-viral }\end{array}$ & $\begin{array}{l}\mathrm{HD} \\
\mathrm{HD}\end{array}$ & $\begin{array}{l}\text { Efficacy vs. DNA copy number } \\
\text { Inflammatory expression, histopathology, PCR }\end{array}$ & $\begin{array}{l}\text { Cholestrolemia } \\
\text { Arthritis }\end{array}$ & $\begin{array}{l}4 \text { months } \\
12 \text { days }\end{array}$ \\
\hline Zhang, G [22] & 2010 & Muscle & full-length Dystrophin Gene & Full length DNA & HD-limb vein & $\begin{array}{l}\text { Distribution, expression, myofibres damage, } \\
\text { Western Blot }\end{array}$ & Duchene & \\
\hline Shahaf, G [105] & 2011 & Liver & hAAT & Epstein Bar Virus-plasmid & $\mathrm{HD}$ & Islet function, Treg, macrophage, IL1 & Islet allogenic transplant & up to 100 days \\
\hline Ochoa, M [71] & 2012 & Liver & IL15+ApoA1+IL15Ra & Expression plasmid cDNA & $\mathrm{HD}$ & $\begin{array}{l}\text { Cell count, pathology, Western Blot, } \\
\text { PCR, cytometry }\end{array}$ & Cancer & 60 days \\
\hline $\begin{array}{c}\text { Holm, DA [37] } \\
\text { Barao, I [72] } \\
\text { Hibbit, O. [106] }\end{array}$ & $\begin{array}{l}2003 \\
2011 \\
2011\end{array}$ & Liver & $\begin{array}{l}\text { SCAD, promoter } \\
\text { genomic elements }\end{array}$ & cDNA & $\mathrm{HD}$, in vitro & Plasma protein, NK reconstitution, toxicity & $\begin{array}{l}\text { Metabolic disease } \\
\text { Immunodeficiency } \\
\text { and transplantation }\end{array}$ & $\begin{array}{l}31 \text { days } \\
18 \text { days }\end{array}$ \\
\hline Dasi, F [3] & 2001 & Liver, Plasma & hAAT & ASF-Lp, PS, DOTAP, NLS & iv + Partial HTx & ELISA, PCR, Sequencing & hAAT deficiency & $\begin{array}{l}6 \text { months \& } \\
12 \text { months }\end{array}$ \\
\hline Wooddell, CI [107] & 2008 & Liver & $\begin{array}{l}\text { Alkaline Phosphatase } \\
\text { Reporter gene }\end{array}$ & Albumin promoter & $\mathrm{HD}$ & Plasma protein & Method & $\begin{array}{l}\text { Albumin } 1 \text { year } \\
\text { vs. CMV } 1 \text { day }\end{array}$ \\
\hline
\end{tabular}




\section{Translation of the Hydrodynamic Method: From Mouse to Large Animals}

In addition to the murine model, naked gene transfer was employed in rats prior to description of the hydrodynamic procedure. Budker et al. [8] showed that high-pressure injection of naked DNA into the hind limb with occluded outflow mediated high expression levels of luciferase in muscle. In the present chapter, we describe the translational process of hydrodynamic procedure through different animal models.

\subsection{Rodents}

Given the promising therapeutic outcomes obtained with the hydrodynamic procedure, research focused on carrying out the translational process of the technique to large animals, with the aim of achieving clinical application. It must be remembered that mouse hydrodynamic injection involved doubling the volemia of the animal within only a few seconds, which induces cardiac overload that cannot be reverted by large animals-with the result of damaging effects. Most of the studies carried out in rats involved conditions similar to those used for mice. However, different adaptations designed to lower the volume of gene solution have been proposed in order to transfer the translation process to the clinical setting. For this purpose, the original hydrodynamic gene transfer procedure had to be adapted to allow safe application in larger animals. One such adaptation was to target reduced areas of the liver.

In a glomerulonephritis (Th1 predominant disease) model in rats, Higuchi et al. [108] employed a procedure for gene transfer identical to that described for mouse hydrodynamic injection in order to transfer a plasmid containing viral interleukin 10 (pCAGGS-vIL10). These authors observed reduced mRNA expression of disease related genes for seven days. The application of hydrofection was also tested in liver transplantation [109]. For this purpose, CTLA4Ig cDNA was injected in vein, achieving high protein expression that allowed lengthening of graft survival time. Another approach involving the hydrodynamic procedure applied to organ xenotransplantation was described by Miki et al. [110] and consisted of depleting the $\alpha \mathrm{Gal}$ protein from erythrocytes and kidney by injecting Igk-EndoGalC (a protein with the capacity to remove $\alpha \mathrm{Gal}$ ). The protein was expressed, with elimination of $\alpha \mathrm{Gal}$ from the vascular endothelium and digestion of $97 \%$ of the protein from erythrocytes for seven days. These effects made it possible to protect the treated rats against specific $\alpha \mathrm{Gal}$ antibodies. The potential applications of the hydrodynamic procedure are so wide that even neurological disorders have been tested [111]. In this sense, human EPO cDNA was injected through the tail vein of rats and remarkable plasma levels of protein were detected for at least 14 days. Improvement in cell protection against hypoxia injury and apoptosis in neurons was reported. The technique has also been applied in nephrology in order to evaluate its potential use in limiting the fibrotic process [112] triggered after unilateral ureteral obstruction. Antisense oligonucleotides have been injected with the aim of silencing the connective tissue growth factor (CTGF) gene. They markedly attenuated the induction of CTGF, fibronectin, fibronectin ED-A and alpha1(I) collagen genes for 14 days, reducing the fibrotic areas.

Other researchers [113] have explored different strategies to improve hydrofection efficiency by targeting the right lateral liver lobe of the rat through a portal vein branch, co-administering chloroquine to promote endocytic escape and including the gene into nanoparticles approximately $100 \mathrm{~nm}$ in diameter. The authors observed transgene expression, such as luciferase activity. Different studies agree that outflow blockade in the target area is needed, since the portal vein pressure is too low to prevent backflow.

The size limitations of nanoparticles in crossing the cell membrane for gene delivery were confirmed by transmission electron microscopy. The potential application of the hydrodynamic strategy for autoimmune myocarditis was evaluated [114] employing equivalent conditions of gene solution volume. To this effect, the interleukin 1 receptor antagonist (IL1RA) gene was injected into the tail vein and 17 days later different clinical parameters such as myocarditis areas, heart weight and heart function were seen to have improved compared with the controls. The expression of inflammation-related genes was also reduced. Employing a similar model of experimental 
autoimmune myocarditis (EAM) in rats, Chang et al. [115] found proinflammatory IL-17 cytokine to be overexpressed. They injected the immunosuppressant IL10-Ig gene and demonstrated that the expression of this transgene suppressed the expression of IL-17 and other proinflammatory cytokines such as TNF alpha and IL-1. Based on the same model, Chang et al. [116] transferred interleukin 18-binding protein (IL18BP). Gene therapy proved effective in controlling EAM, as monitored by a decreased ratio of heart weight to body weight, reduced myocarditis areas, reduced expression of atrial natriuretic peptide, brain natriuretic peptide, IL-17, IFN- $\gamma$, IL-6 and IL-10. These effects were likewise suggested to be due to the suppression of IL-17.

On the other hand, the efficacy of gene expression after hydrofection was evaluated in a model of liver transplantation in rats [117]. Different volumes of gene solution, types of promoters and different doses of luciferase and hAAT plasmids were used. Transgenes were efficiently expressed, with hAAT protein being present in plasma for at least 21 days (with peak levels on day 7); CMV mediated more efficient gene expression. Larger volumes caused more damage, without associated important improvement in gene expression and a limit in gene expression was observed that could not be overcome by increasing the dose of plasmid administered. As already described in application to mice, liver fibrosis is a target disease for hydrodynamic gene therapy and has also been studied in a rat model [118]. Platelet-derived growth factor receptor $\beta$ subunit (PDGFR-b) was downregulated by gene silencing with siRNA and fibrotic pathways were suppressed, improving the clinical status of the liver.

As part of the hydrodynamic procedure translational process, automation and reproducibility of gene injection are required. With this aim in mind, Suda et al. [96] designed a computerized injector that was shown to mediate efficient expression of luciferase in mouse (liver), rat (kidney and muscle) and pig (kidney and liver). Having demonstrated the possibility of gene delivery and transgene expression, researchers sought to improve the efficiency of the procedure. In this regard, ultrasound exposure has been found to enhance (up to 4.5-fold) the efficiency of hydrodynamic-based gene delivery for both luciferase and EPO expression within the rat kidney, without altering the histological structure or impairing physiological function of the treated kidney [119]. In another attempt to improve the efficiency of the procedure, the left liver lobe was targeted in rats and outflow occlusion was performed to compare its effect with free-flow control rats [120]. Outflow blockade was described as absolutely necessary to obtain efficient outcomes in transgene expression in several orders of magnitude, as determined by luminescence. Cim et al. [121] studied the potential interest of the procedure in treating type 1 diabetes in rats. The authors aimed to transdifferentiate hepatocytes into pancreatic $\beta$ cells to produce insulin. The $P d x 1, N g n 3$ (Neurog3) and MafA genes were injected, singly and in combination, to livers of normoglycemic rats. Different expression plasmids bearing DNA and mRNA of these genes were used and insulin was detectable in liver for 28 days. Insulin mRNA levels were close to those observed in the pancreas of normal rats 7 days after treatment but declined thereafter.

It has also been reported that the hydrodynamic procedure may be interesting in application to hypertensive rats. The injection of human hepatocyte growth factor (HGF) has been shown to normalize renal NF- $\mathrm{kB}$ activity, proinflammatory cytokines, antioxidant status (GSH, SOD and CAT) and Na+-ATPase activity, reduce renal injury and ameliorate hypertension after 6 weeks of weekly gene administration. The applicability of hydrofection is truly wide and not only circumscribed to the liver, kidney, heart and muscle. Its use in the treatment of peritoneal endometriosis [122] has been evaluated in rats by intravenous injection of a delivery system composed of lipid-grafted chitosan micelles (CSO-SA) and the pigment epithelium derived factor (PEDF). The procedure significantly reduced the size of the endometrial lesions, atrophy and degeneration of ectopic endometrium, without toxic effects. In a model of liver failure in rats, researchers [123] injected c-met cDNA and observed transgene overexpression within the hepatocytes accompanied by proliferation enhancement, reduced apoptosis, as well as significant improvement in overall survival. In another study in rat kidney, efficiencies of adenoviral and baculoviral vectors were compared with the efficiency of naked DNA 
injection. Widespread fluorescent protein expression was observed for more than one month after transgene introduction. Plasmid and adenoviral vectors yielded gene transfer efficiencies ranging from 50-90\%, compared with 10-50\% mediated by baculovirus vector.

Liver hydrodynamic gene transfer is able to exert its therapeutic action both in liver and anywhere else in the organism. In this sense, the technique has been found to play an interesting role in the treatment of osteoporosis. The transfer of insulin-like growth factor 1 (IGF-1) gene in an ovariectomized rat model of osteoporosis showed remarkable expression of fluorescence, serum presence of IGF-1 and significant alleviation of osteoporosis. As an interesting approach to the treatment of mitochondrial diseases, Yasuzaki et al. [124] demonstrated that the hydrodynamic gene transfer of naked DNA could mediate gene access to the skeletal muscle mitochondrion after hind limb injection, opening an important field of research.

\subsection{Rabbit to Pig}

The hydrodynamic procedure has achieved promising results in rodents. However, in order to allow clinical application, the translational process and its safety and efficiency had to be demonstrated in larger animals. The problem was that larger animals could not tolerate the demanding hemodynamic conditions of the injection. For this reason, different approaches designed to reduce the volume of gene solution have been proposed, such as targeting a specific organ or a segment of an organ by partially or completely excluding its vascularization.

In this regard, Eastman et al. [125] injected a reporter gene in rabbit liver using two strategies: (a) targeting a single liver lobe employing a balloon catheter; and (b) targeting the entire organ with hepatic venous occlusion. The authors achieved protein plasma expression over two days, with higher levels when the whole liver was targeted. The safety of liver hydrodynamic gene transfer was also assessed in dogs in order to assess its application to large animals [126]. Four successive injections of $250 \mathrm{~mL}$ of hAAT, FIX or Luciferase gene solution were made in four different main liver lobes and numerous variables were evaluated, such as transaminases and cytokines. The authors observed no significant harmful effects and recovery of the animals was rapid.

The following step in clinical translation of the procedure was to test its potential use in animals closer in size and anatomy to humans, such as pigs and primates.

Yoshino et al. [127] and Aliño et al. [128] independently described the first attempts in pigs. They reduced the total volume employed by targeting an area of liver and compared different delivery strategies mediated by catheterization. The strategies tested were: portal vein occlusion, left hepatic artery occlusion, portal vein and left hepatic artery occlusion and the occlusion of both vessels with blood flow washout. Yoshino et al. injected the gene solution $(150 \mathrm{~mL})$ carrying eGFP or CTLA4-Ig gene at $5 \mathrm{~mL} / \mathrm{s}$ through the cava vein. Occlusion of the portal vein and hepatic artery with washout mediated the most efficient outcomes, achieving disperse fluorescence in liver tissue (due to eGFP gene) and CTLA4-Ig protein plasma levels for several weeks, with expression peaks of up to $161 \mathrm{ng} / \mathrm{mL}$ one day after treatment. This was the first time the procedure was described in pigs, yielding results of interest for proteins with low levels of expression. In another work, large and small areas of liver were targeted for retrovenous hydrofection in pigs. Aliño et al. [128] reported the presence of gene in liver tissue, as determined by semi-quantitative PCR. Protein expression was also observed by immunohistochemical evaluation in tissue, mainly within the perivenous area. This work also confirmed (by transmission electron microscopy) the previously described [17] formation of endocytic vesicles after hydrodynamic gene delivery in liver. On targeting smaller liver areas while injecting the same volumes of gene solution, the plasma protein levels two weeks after injection reached up to $200 \mathrm{ng} / \mathrm{mL}$ - such levels being much lower than those regarded as therapeutic. Fabre et al. [129] targeted the entire liver and isolated the hepatic segment of the inferior vena cava by clamping it supra- and infrahepatically. Gene solution $(400 \mathrm{~mL})$ was transferred at $100 \mathrm{~mL} / \mathrm{s}$ through two parallel syringes and although the efficiency of gene delivery (measured by luciferase) was much lower than 
that observed in mouse and rat, the authors confirmed the clinical feasibility and safety of the technique as determined by systemic blood pressures, electrocardiography, heart rate, etc.

In parallel to the development of liver hydrofection in large animals, other possible applications of the procedure were also tested. In this regard, cardiac gene transfer by an adaptation of the hydrodynamic procedure was studied [18]. A naked eGFP-carrying plasmid was injected $(50 \mathrm{~mL}$; $20 \mu \mathrm{g} / \mathrm{mL}$ ) through the coronary sinus at $5 \mathrm{~mL} / \mathrm{s}$ employing a catheter, while another catheter fitted with a balloon was placed proximally within the sinus to block outflow. This procedure yielded efficient gene delivery (1-200 copies of gene per haploid genome), exhibiting a relative transcription rate with respect to the GAPDH gene of 0.2-10 mRNA copies. The expression of protein was observed by immunohistochemistry. That same year, the efficiency of the hydrodynamic procedure in application to skeletal muscle gene transfer in pigs [130] was demonstrated by the expression of luciferase after gene transfer $(100 \mu \mathrm{g} / \mathrm{mL})$ in the hind limb. In the hands of these authors, the injection of $300 \mathrm{~mL}(1.5 \%$ of body weight) of luciferase gene solution at $15 \mathrm{~mL} / \mathrm{s}$ and $300 \mathrm{psi}$ pressure yielded $10^{6}-10^{7} \mathrm{RLU} / \mathrm{mg}$ of protein 5 days after injection and gene expression in transfected cells was maintained for two months. Given the important role of the pressure reached within the liver during hydrodynamic injection, Fabre et al. [131] focused on pressurizing individual liver lobes by excluding their vasculature. Seeking to achieve localized high-pressure levels without affecting the systemic circulation, these authors proposed individualizing the lobes by employing catheters with balloons and ligation. Luciferase gene $(200 \mathrm{~mL})$ was injected through individual branches of the portal vein to targeted liver lobes at $50 \mathrm{~mL} / \mathrm{s}$, with occlusion of their tributary suprahepatic cava vein and without occluding normal portal flow and cardiac load. This strategy allowed the reaching of intrahepatic pressure levels of up to $100 \mathrm{mmHg}$.

Although most authors have pointed to blood pressure as the most important feature of hydrodynamic injection in mediating efficient gene transfer, other investigators have described other characteristics of injection, such as impulse [84] and flow rate [132,133], as being of relevance. In any case, almost all authors agree on the need or benefit of isolating target areas or the entire liver by vascular exclusion in order to improve the efficiency of the procedure. Such vascular isolation may be partial or complete. It had been previously reported that the complete liver vascularization of the pig could be occluded for up to $20 \mathrm{~min}$ without hepatic injury or systemic damage [134]. Based on this fact, Carreño et al. [132] described a surgical procedure for completely sealing the pig liver in vivo and performing the hydrofection targeted to the whole organ. An eGFP gene $(20 \mu \mathrm{g} / \mathrm{mL})$ saline solution $(200 \mathrm{~mL})$ was injected at 10,20 and $60 \mathrm{~mL} / \mathrm{s}$ simultaneously through the suprahepatic inferior cava vein and the portal vein using two catheters connected by a Y-connector and a high-volume pump. Optimal conditions were found to be the retrograde injection of $200 \mathrm{~mL}$ at $20 \mathrm{~mL} / \mathrm{s}$. Due to the invasiveness of the surgical procedure, same authors adapted this model for sealing the liver venous system through catheterization [21]. Two strategies (Figure 3) were proposed and compared: (a) the use of a balloon catheter for insertion into a single lobe; and (b) the use of three catheters with balloons simultaneously placed within the supra- and infrahepatic inferior cava vein and in the portal vein, around entry to the liver. The procedure involving complete venous obstruction and entire organ targeting adopting the suprahepatic inferior cava vein route yielded greater gene delivery, transcription and translation in liver tissue 14 days after injection-achieving more than $10^{5}$ copies of hAAT protein per cell. However, the presence of protein in plasma was dramatically lower (more than 4 orders of magnitude) - a fact that could be due to differences between species. Catheterization-mediated hydrodynamic gene delivery in a single lobe was also used to compare the efficacies of the naked DNA and foamy viral vector strategies [135]. The eGFP gene was transferred in a naked plasmid and in a foamy viral vector. The presence and expression of $e G F P$ was determined one week and one month after transfer by PCR and qPCR versus GAPDH, assessed as $\triangle \triangle \mathrm{Ct}$. The authors recorded better outcomes using viral vector, with expression levels of up to $29.7 \%$ of the endogenous GAPDH levels. 


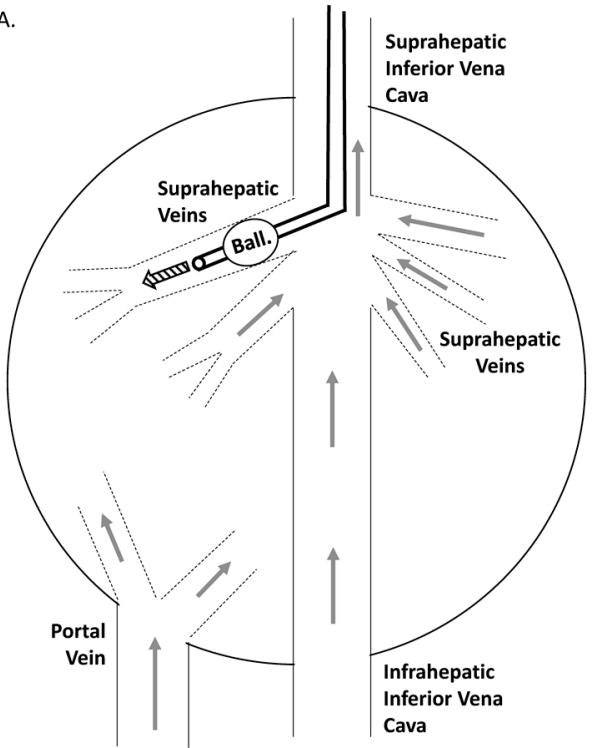

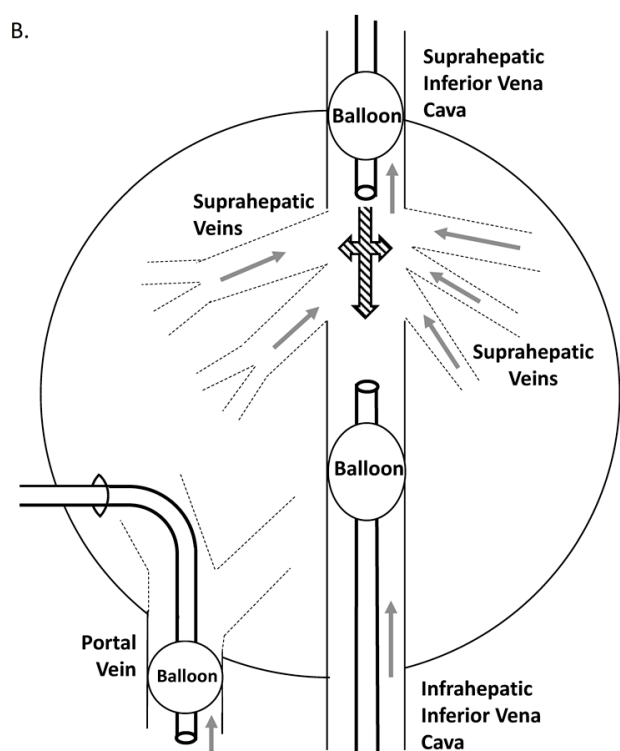

Figure 3. Catheterization strategies for minimally invasive liver hydrofection 'in vivo.' Schematic representation of liver venous vasculature and catheters position. Continuous line represents extrahepatic vessels. Gapped lines represent intrahepatic vasculature. Grey arrows indicate the normal blood flow sense. Black thick arrows indicate the sense of hydrodynamic injection.

Open procedure model (left panel): catheterization was carried out through the jugular vein with an 8 Fr balloon catheter placed in a suprahepatic branch.

Closed procedure model: The catheter-mediated liver vascular isolation was performed by simultaneous catheterization of the intrahepatic portal vein (transhepatic catheterization with a $10 \mathrm{Fr}$ balloon catheter) and both the supra- and infrahepatic inferior cava vein (two $8 \mathrm{Fr}$ balloon catheters through the jugular and femoral veins), with balloons limiting the perfusion area. This permitted excluding the entire liver venous vasculature.

\subsection{Primates}

Different gene therapy attempts have been carried out in primates [93], with the aim of transferring genes to skeletal muscle, through the hind limb with occluded outflow. This strategy proved efficient for the expression of plasmid DNA and/or siRNA, as determined by luciferase quantification. Wooddell et al. [98] tested the expression efficacy of different LacZ tracer gene constructs driven by different promoters in mice, rats and rhesus monkeys. They determined the long-term (up to 49 weeks) expression of LacZ in mice, with better outcomes being recorded when employing the CMV promoter. Despite the different gene therapy studies carried out in primates, most of them $[136,137]$ have employed viral vectors to transfer genes to skeletal muscle and liver. However, the ethical implications, the lack of clinical response (possibly limited by viral particle size) and the difficulty of working with this animal model have limited its use and researchers have focused especially on pigs.

The applications of hydrodynamic gene therapy in middle to large size animals are summarized in Tables 2 and 3. 
Table 2. Hydrodynamic gene transfer works performed in mid-size animals. The table shows the author of each work, the publication year, the animal model studied, the target organ assayed, gene and gene construction, injection methodology, variables evaluated, disease of interest and effect duration.

\begin{tabular}{|c|c|c|c|c|c|c|c|c|c|}
\hline Author & Year & Species & Organ & Gene & Gene Construct & Methodology & Variables & Disease & $\begin{array}{l}\text { Long-Term } \\
\text { Expression }\end{array}$ \\
\hline Budker, V [8] & 1998 & Rat & Muscle & $b$-Gal, luciferase & $\begin{array}{l}\text { Naked, Solution } \\
\text { hypo/hypertonic }\end{array}$ & $\begin{array}{l}\text { Artery injection High } \\
\text { pressure (hind-limb) }\end{array}$ & Histochemistry, Luciferase & 2 days & \\
\hline Eastman, SJ [125] & 2002 & Rabbit & Liver & $\begin{array}{l}\text { Alkaline Phosphatase } \\
\text { Reporter gene }\end{array}$ & DNA & $\begin{array}{l}\text { HD catheter lobar and } \\
\text { whole liver }\end{array}$ & $\begin{array}{l}\text { Plasma Alkaline } \\
\text { Phosphatases }\end{array}$ & Model & 2 days \\
\hline Hagstrom, JE [93] & 2004 & $\begin{array}{l}\text { Mouse, Rat, } \\
\text { Dog, Primate }\end{array}$ & Muscle & $\begin{array}{l}\text { DNA Luc vs. Ad; } \\
\text { EPO; Distr }\end{array}$ & DNA, siRNA, Ad & HD vein limb & Luciferase & 30 days & \\
\hline Inoue, S [109] & 2004 & Rat & Liver & $\begin{array}{l}\text { b-Gal, luc-image, } \\
\text { CTLA4Ig }\end{array}$ & DNA dosing CTLA4Ig & $\begin{array}{l}\text { HD system and local- } \\
\text { catheter }\end{array}$ & Transplantation & 2 days & \\
\hline Zhang, X [113] & 2004 & \multirow{3}{*}{ Rat } & \multirow{3}{*}{ Liver } & Luciferase & DNA & HD vs. regional Portal & \multirow{3}{*}{$\begin{array}{c}\text { Luciferase } \\
\text { Injury, histopathology, } \\
\text { physiology, efficacy } \\
\text { IL-17, IL1beta, TNFa, IL1 .. }\end{array}$} & Method & \multirow{3}{*}{$\begin{array}{l}\text { short } \\
>5 \text { days }\end{array}$} \\
\hline Tosoulfas, G [117] & 2006 & & & $h A A T, L u c$ & DNA & \multirow{2}{*}{$\begin{array}{l}\text { HD ex vivo DNA } \\
\text { injection IVC closed }\end{array}$} & & Transplantation & \\
\hline Chang, H. [115] & 2008 & & & IL10-Ig fusion gene & DNA & & & Myocarditis & \\
\hline Suda, T [96] & 2008 & $\begin{array}{l}\text { Mouse, } \\
\text { Rat, Pig }\end{array}$ & $\begin{array}{c}\text { Liver, } \\
\text { Kidney, Muscle }\end{array}$ & Luc, GFP, Ad-GFP & DNA, Ad & HD computer assisted & $\begin{array}{c}\text { Pressure, gene } \\
\text { delivery/expression }\end{array}$ & & \\
\hline Xing, Y [119] & 2009 & Rat & Kidney & Luc, EPO & & $\begin{array}{l}\mathrm{HD} \text { and ultrasound } \\
\text { combination }\end{array}$ & Method & & \\
\hline Sawyer, GJ [120] & 2010 & Rat & Liver & Luc & DNA & $\begin{array}{l}\text { HD-Regional Lobe } \\
\text { without occlusion }\end{array}$ & Efficacy, luciferase activity & Method & \\
\hline Wooddell, C [98] & 2011 & $\begin{array}{l}\text { Mouse, Rat, } \\
\text { Rhesus monkey }\end{array}$ & Muscle & LacZ & $\begin{array}{l}\text { Plasmid DNA } \\
\text { complexes }\end{array}$ & HD hind limb & Expression and delivery & null & 49 weeks \\
\hline Cim, A [121] & 2012 & Rat & Liver & $P d x 1, N g n 3$, MafA & $\begin{array}{l}5 \text { different expression } \\
\text { plasmids }\end{array}$ & $\mathrm{HD}$ & Expression, PCR, IHC & Diabetes type 1 & 28 days \\
\hline Romero-Vasquez, F [138] & 2012 & Rat & Liver & $\begin{array}{l}\text { hepatocyte growth } \\
\text { factor }\end{array}$ & $\mathrm{pCMV}$ & $\mathrm{HD}$ & $\begin{array}{l}\text { NFkB, RANTES, MCP1, IL6, } \\
\text { oxidative stress }\end{array}$ & $\begin{array}{c}\text { Renal } \\
\text { hypertension }\end{array}$ & $\begin{array}{c}6 \text { weeks with } \\
\text { weekly } \\
\text { treatment }\end{array}$ \\
\hline Zhao, M [122] & 2012 & Rat & Endometrium & $\begin{array}{l}\text { pigment epithelium } \\
\text { derived factor }\end{array}$ & Polymeric micelle & intravenous injection & $\begin{array}{l}\text { Clinic observation of } \\
\text { endometrium lesions }\end{array}$ & Endometriosis & \\
\hline Corridon, PR [139] & 2013 & Rat & Kidney & $\begin{array}{c}\text { eGFP, eGFP- } \\
\text { actin/occluding/tubulin, } \\
\text { tdTomato-H2B, } \\
\text { RFP-actin }\end{array}$ & $\begin{array}{l}\text { Plasmid, adenovirus, } \\
\text { baculovirus }\end{array}$ & $\begin{array}{l}\text { HD retrograde renal } \\
\text { vein }\end{array}$ & $\begin{array}{l}\text { Expression-intravital, } \\
\text { confocal }\end{array}$ & 1 month & \\
\hline De La Vega, J [140] & 2013 & $\begin{array}{l}\text { Chinese } \\
\text { hamster }\end{array}$ & Ovary cells & GFP & $\begin{array}{c}\text { Plasmid lipofectamine } \\
\text { lipoplexes }\end{array}$ & $\begin{array}{l}\text { Methods of plasmid } \\
\text { purification }\end{array}$ & $\begin{array}{l}\text { Hydrodynamic diameter and } \\
\text { zeta potential }\end{array}$ & & \\
\hline Yasuzaki, Y [124] & 2013 & Rat & Muscle & Luc & DNA & HD-hindlimb & $\begin{array}{l}\text { Expression, luminescence, } \\
\text { qPCR, WB }\end{array}$ & Method & $24 \mathrm{~h}$ \\
\hline Kamimura, K [126] & 2014 & Dog/Rat & Liver & Luc, hAAT, hFIX & Plasmid cDNA/DNA & $\begin{array}{l}\text { HD-through hepatic } \\
\text { veins of each } 4 \text { lobes } \\
\text { with closed cava vein }\end{array}$ & $\begin{array}{l}\text { Histology, physiological } \\
\text { parameters }\end{array}$ & 6 weeks & \\
\hline
\end{tabular}


Table 3. Hydrodynamic gene transfer works performed in large animals. The table shows the author of each work, the publication year, the animal model studied, the target organ assayed, gene and gene construction, injection methodology, variables evaluated, disease of interest and effect duration.

\begin{tabular}{|c|c|c|c|c|c|c|c|c|c|}
\hline Author & Year & Species & Organ & Gene & Gene Construct & Methodology & Variables & Disease & $\begin{array}{l}\text { Long-Term } \\
\text { Expression }\end{array}$ \\
\hline Hagstrom, JE [93] & 2004 & $\begin{array}{l}\text { Mouse, Rat, } \\
\text { Dog, Primate }\end{array}$ & Muscle & $\begin{array}{l}\text { DNA Luc vs. Ad; } \\
\text { EPO; Distr }\end{array}$ & DNA, siRNA, Ad & HD vein limb & Luciferase & 30 days & \\
\hline Yoshino, H [127] & 2006 & Pig & Liver & GFP, CTLA4-Ig & DNA & $\begin{array}{c}\text { HD-cathe, closed } \\
(3 \mathrm{mg}, 150 \mathrm{~mL}, 5 \mathrm{~mL} / \mathrm{s})\end{array}$ & $\begin{array}{l}\text { Physiology, histology, } \\
\text { fluorescence, plasma } \\
\text { presence }\end{array}$ & Method & $\begin{array}{c}1 \text { day }(161 \mathrm{ng} / \mathrm{mL})- \\
7 \text { days }\end{array}$ \\
\hline Alino, SF [128] & 2007 & Pig & $\begin{array}{l}\text { Liver (small vs. } \\
\text { Large) }\end{array}$ & $h A A T$ & DNA & $\begin{array}{l}\text { HD-Cathe, open } \\
(100 \mathrm{~mL}, 7.5 \mathrm{~mL} / \mathrm{s})\end{array}$ & ELISA, IHC, injury, qRT-PCR & $\begin{array}{c}\text { hAAT } \\
\text { deficiency }\end{array}$ & $\begin{array}{c}15 \text { days } \\
(200 \mathrm{ng} / \mathrm{mL})\end{array}$ \\
\hline Fabre, JW [129] & 2008 & Pig & Liver & $p G L 3$ plasmid, $L u c$ & DNA & $\begin{array}{l}\text { HD-isolated segment } \\
\text { of IVC }\end{array}$ & $\begin{array}{c}\text { Pressure, ECG, heart rate, } \\
\text { luciferase activity }\end{array}$ & Method & 1 day \\
\hline Aliño, SF [18] & 2010 & Pig & Heart & EGFP, GAPDH & Naked & HD Cath Coronary sinus & $\begin{array}{c}\text { IHC, PCR, RT-PCR, } \\
\text { copy number }\end{array}$ & Method & 1 day \\
\hline Kamimura, K [130] & 2010 & Pig & Muscle & $p C M V-L u c$ & DNA & HD hindlimb & Luciferase activity [95] & Method & 60 days \\
\hline Fabre, JW [131] & 2011 & Pig & Liver segment & Luc & DNA & $\begin{array}{l}\text { Surg-HD-LivSeg portal } \\
\text { vs. hepat vein }\end{array}$ & $\begin{array}{c}\text { Vascular pressure } \\
(>100 \mathrm{mmHg})\end{array}$ & Method & Short \\
\hline Hackett, PB [84] & 2011 & $\begin{array}{l}\text { Small\&Large } \\
\text { animals/Rev }\end{array}$ & Liver & Luc & $\begin{array}{l}\text { Sleeping Beauty } \\
\text { Transposon }\end{array}$ & $\mathrm{HD}$ & Integration, Plasma presence & & \\
\hline Wooddell, C [98] & 2011 & $\begin{array}{c}\text { Mouse, Rat, } \\
\text { Rhesus monkey }\end{array}$ & Muscle & LacZ & $\begin{array}{l}\text { Plasmid DNA } \\
\text { complexes }\end{array}$ & HD hind limb & Expression and delivery & 49 weeks & \\
\hline Zacharoulis, D [135] & 2013 & Pig & Liver & eGFP & $\begin{array}{l}\text { Plasmid DNA vs. } \\
\text { foamy virus } \\
\text { vector-based }\end{array}$ & $\mathrm{HD}$ & Gene expression and qPCR & $\begin{array}{l}1 \text { week to } \\
1 \text { month }\end{array}$ & \\
\hline Sendra, L [133] & 2014 & Pig & Liver & eGFP & Plasmid cDNA & $\begin{array}{l}\text { HD-surgical isolation } \\
\text { cava vs. porta }\end{array}$ & $\begin{array}{c}\text { Gene and protein expression, } \\
\text { qPCR, ELISA, TEM }\end{array}$ & 1 day & \\
\hline Kamimura, K [141] & 2015 & $\begin{array}{c}\text { Small and large } \\
\text { animals }\end{array}$ & Liver & Various & Non-viral & $\mathrm{HD}$ & & Various & \\
\hline Sendra, L [19] & 2016 & Pig & Liver & $h A A T$ & Plasmid DNA & $\begin{array}{l}\text { HD-open vs. } \\
\text { closed catheterism }\end{array}$ & $\begin{array}{l}\text { Tissue expression qPCR, } \\
\text { ELISA, clinic observations }\end{array}$ & $\begin{array}{c}\text { hAAT } \\
\text { deficiency }\end{array}$ & 14 days \\
\hline
\end{tabular}




\section{Parameters of the Genes Transfer Process}

The efficacy of gene transfer can be measured by different procedures and authors have studied many variables to present their results and evaluate how efficient a procedure is and how interesting it could be for clinical application. When the murine model and standard efficient hydrodynamic injection is employed, protein translation is efficient and quantifiable both within tissue (immunohistochemistry, Western blot, ELISA) and eventually also in the bloodstream (ELISA). After confirmation of the optimum response of hydrodynamic gene therapy in the murine model, the development of new animal models, different delivery strategies and gene constructs, etc. involving less efficacious protein production, required other parameters for the expression of results. In this regard, a detailed analysis was needed to establish the effectiveness of each stage of the gene decoding process. Such evaluation was able to identify the steps limiting the efficacy of the procedure. In this chapter, we suggest a quantitative manner of evaluating the molecular process of gene decoding that could facilitate the comprehension and reporting of gene expression results.

The molecular evaluation of decoding is mandatory for correct interpretation of the process. The determination of DNA, mRNA and protein can be qualitative, semi-quantitative or quantitative. Qualitative analyses only allow identification of the presence of a molecular species, without possible interpretation of the efficiency of the procedure, gene construct, etc. The semi-quantitative determination of nucleic acids has been widely employed and consists of expressing the relative amount of DNA or mRNA based on the presence of a housekeeping gene. This strategy has limitations that impede correct evaluation and comparison of different procedures, such as differences in the housekeeping genes employed or different gene expressions depending on the cell type and situation involved-thereby precluding the obtainment of real information on the amount of the specific molecular species. Western blot is used for the semi-quantitative determination of protein. This technique allows us to observe the presence and approximate amount of protein by comparison with other samples or purified protein in known quantities. Quantitative determination of the molecular process in turn affords real data on delivery, transcription and translation indexes expressed as the number of copies per cell of the respective molecular species. In the case of DNA and mRNA, real-time quantitative PCR is required. The data obtained for samples must be plotted on a standard curve prepared with a defined amount of the same gene construct injected. For protein quantitation, the ELISA technique with a standard curve prepared with serial dilutions of the purified protein is performed. By knowing the molecular weight of each molecular species, the exact number of molecules present in a unit volume and/or weight can be determined. Different reference units have been proposed: total protein weight, total organ weight, total DNA/RNA/protein, etc. In order to facilitate comparison of the results and objectively define the best conditions for gene transfer, authors should reach consensus on data quantitation and expression.

When a secretion protein is employed and its presence in plasma is evaluated, we suggest that the pharmacological term efficacy should be maintained, defined as the amount of protein in plasma per dose of DNA employed. The results should be expressed in molecular units (e.g. number of copies or moles) whenever possible or opportune, or alternatively in units of mass. This would make it possible to establish the optimum doses for potential treatment. We suggest evaluating the expression of transfected gene in a quantitative and objective manner, employing a universal standard reference. Since the cell is the biological reference unit, we consider that the amount of DNA, RNA and protein should be related to a normalized cell. When the results are evaluated in cultured cells or tissues, the data should be referred to a common circumstance such as a standard or "normalized cell." Such data make wide sense in the majority of studies from different areas. A normalized cell has been described [142] as having the following average characteristics: weight $3-4 \mathrm{ng}$ with a volume of $\approx 1 \mathrm{pl}$ and a diameter of $\approx 10 \mu \mathrm{m}$, depending on the cell type. The total protein content of a cell is $\approx 700 \mathrm{pg}$ but the dynamic range of concentration can span up to 7 orders of magnitude [143]. The mass of genomic diploid DNA in a human cell is estimated to be $\approx 6.6 \mathrm{pg}$, whereas that of RNA is $\approx 10-20$ pg [144]. 
A normalized diploid cell was classically described by Alberts et al. as a typical mammalian hepatocyte with a defined content of total DNA (genome weight of the specific animal, human: $6.6 \mathrm{pg}$ ), RNA (20 pg) and protein (500 pg)—and these are the parameters we employed as reference.

Three types of parameters can be used in seeking to objectively assess the efficiency of the gene transfer procedure step-by-step, minutely at molecular level:

(a) Indexes, for the absolute number of copies of each molecular species (DNA, RNA or protein) referred to a normalized cell.

(b) Intrinsic activities, representing the index ratio between consecutive steps (transcription (RNA/DNA) and translation (protein/RNA)) of the decoding process, in order to evaluate how efficient each step is, in a normalized cell.

(c) Expression efficacy, defining the final efficacy of the procedure in the tissue relating the amount of protein copies per gene copy, in a normalized cell.

The formulas of each parameter can be defined as follows:

Index formulas:

- Delivery index: transgene DNA copy number/animal diploid genome weight. Example for humans:

Delivery index $=X$ transgene copies $/ 6.6$ pg of total DNA

- Transcription index: transgene RNA copy number/20 pg of total RNA. Example for mammalian cells:

Transcription index $=X$ transgene mRNA copies $/ 20$ pg total RNA

- Translation index: transgene protein copy number/500 pg of total protein. Example for mammalian cells:

Translation index $=X$ transgene protein copies $/ 500 \mathrm{pg}$ total protein

Intrinsic activity formulas:

- Transcription activity: (transgene RNA copy number/20 pg of total RNA)/(transgene DNA copy number/animal diploid genome weight). Example for human cells:

Transcription activity $=(X$ transgene mRNA copy number $/ 20 \mathrm{pg}$ of total RNA $) /(\mathrm{X}$ transgene DNA copy number $/ 6.6 \mathrm{pg}$ total DNA)

- Translation activity: (transgene protein copy number/500 pg of total protein)/(transgene RNA copy number $/ 20$ pg of total RNA). Example for mammalian cells:

Translation activity $=(X$ transgene protein copy number $/ 500 \mathrm{pg}$ of total protein $) /($ transgene $\mathrm{RNA}$ copy number $/ 20 \mathrm{pg}$ of total RNA)

The efficacy of gene expression relates the protein translation index to the gene delivery index in order to define the global efficacy of the procedure.

The formulas referred to gene expression efficacy are defined as:

- Expression efficacy: evaluated from organ tissue or cell culture.

Expression efficacy $=($ transgene protein copy number $/ 500 \mathrm{pg}$ of total protein $) /($ transgene DNA copy number/animal diploid genome weight)

- Efficacy: evaluated from plasma or extracellular fluid. Classically, final efficacy is expressed as plasma concentration of protein $(\mathrm{w} / \mathrm{v})$ related to the dose of DNA $(\mathrm{w})$ administered (protein $(\mathrm{w} / \mathrm{v}) / \mathrm{DNA}(\mathrm{w}))$. In order to easily relate this with the abovementioned parameters, the dose and concentration should be expressed in moles (protein $(\mathrm{mol} / \mathrm{v}) / \mathrm{DNA}(\mathrm{mol})$ ).

Efficacy $=$ concentration of protein $(\mathrm{w} / \mathrm{v}) /$ dose of DNA $(\mathrm{w})$ administered .

We consider this strategy to offer an objective and clear analysis that enables expression of the data as a ratio of copy number of each molecular species (regarding the usual content of DNA, RNA and protein) in a normalized cell. This offers a more comprehensive and visual interpretation of the entire process and allows comparison of the results from different works and research groups. Furthermore, the intrinsic activities and expression efficacy allow us to identify the limiting steps of the decoding process and establish optimum doses for treatment. 


\section{Hydrodynamic Genes Transfer to Human Organ Ex Vivo}

The hydrodynamic procedure has been shown to be highly efficient in the murine model, achieving therapeutic plasma levels of human proteins of clinical interest. Clinical translation to larger animals has been partially disappointing in terms of final protein secretion. This lack of efficiency has been reported to be due to interspecies differences during protein folding and/or exportation. However, positive results in tissue gene decoding have been recorded, showing effective protein translation within liver tissue. The translational procedure in animal models has been completed and this limitation could only be circumvented by employing human tissue. Thus, application of the hydrofection strategy in human ex vivo models is justified, since this could complete the translational process prior to implementing a clinical trial. In the present chapter, different adaptations for employing human tissues as a target and solve the obvious limitations of in vitro models are described.

\subsection{Isolated Human Organ Segments}

Liver segments from surgical resection are a good option, since they have the required features for optimum hydrofection: the vasculature is preserved and catheters can be placed within them. Furthermore, retrograde injection through a suprahepatic vein can be performed and complete sealing is established due to the surgical intervention. Herrero et al. [145] employed such human liver segments to retrogradely inject a eGFP plasmid $(20 \mu \mathrm{g} / \mathrm{mL})$ driven by a CMV promoter through a short $9 \mathrm{Fr}$ catheter placed in a suprahepatic vein. Different injection conditions were compared to establish the most appropriate ones: volumes equivalent to $1 / 5$ or $1 / 10$ segment weight and flow rates of 1,10 and $20 \mathrm{~mL} / \mathrm{s}$.

Protein expression and tissue distribution, evaluated by fluorescent and immunohistochemistry studies, showed good and wide gene expression and the quantitative molecular analyses reinforce the histological findings. Employing similar human liver segments from surgical resection, Sendra et al. [146] hydrodynamically injected a volume equivalent to $1 / 5$ of the liver segment weight of interleukin-10 plasmid solution $(20 \mu \mathrm{g} / \mathrm{mL})$ at 10 and $20 \mathrm{~mL} / \mathrm{s}$. Interleukin-10 protein is not produced naturally in liver and its levels within liver tissue are low. For this reason, the presence of IL10 protein within liver could be considered as produced by the plasmid hydrofection. Regarding the results previously reported by our group [147] in pig heart in vivo, the indexes referred to tissue IL-10 expression (over 100 copies/cell $[145,146]$ ) could mediate local immunosuppressant pharmacological effects of interest for controlling the immune response (the IC50 of IL-10 for TNF $\alpha$ being $124 \mathrm{pg} / \mathrm{mL}$ [148]) triggered after liver transplantation.

This model allowed evaluation of the efficiency of human gene transfer and decoding in human liver tissue. Given the interest of this strategy for transferring genes to human organs, the human liver segment hydrofection procedure was adapted [149] to human colon segments. The segments from surgical tumour resection maintain the complete vasculature of the segment, allowing injection of the gene solution under hydrodynamic conditions. The $h I L-10$ gene $(20 \mu \mathrm{g} / \mathrm{mL})$ solution was retrogradely injected in tumour-bearing colon segments $(50 \mathrm{~mL}$ at $20 \mathrm{~mL} / \mathrm{s})$ and the presence of IL-10 DNA, RNA and protein was quantified. The procedure mediated a protein translation index in tissue of up to 1000 copies / cell—this being close to the values obtained in liver. As a preliminary experiment, one colon segment with inflammatory bowel disease was also used [149] to evaluate the potential interest of the procedure in treating disease. The procedure mediated similar levels of tissue protein translation (around 1000 molecules per cell). This production of protein could have immunosuppressant pharmacological effects of interest for the treatment of inflammatory disorders. The applications of hydrodynamic gene therapy in humans are summarized in Table 4. 
Table 4. Expression of hAAT-flag in human liver segments after hydrodynamic gene transfer. Preliminary results of hAAT-flag protein expression in human liver tissue after the hydrodynamic delivery of its gene. The first column of the table shows the number of human liver segment (HL1-4), second column indicates the total amount of hAAT protein in liver tissue (including hAAT and hAAT-flag) expressed in copy number per cell. The third column shows the specific amount of hAAT-flag protein. The fourth column represents the ratio between the amount of hAAT-flag protein respect to the total amount of hAAT as percentage.

\begin{tabular}{cccc}
\hline Human Liver & Total hAAT (copy/cell) & hAAT-flag (copy/cell) & hAAT-f/Total hAAT (\%) \\
\hline 1 & $7.16 \times 10^{5}$ & $3.89 \times 10^{5}$ & 54.31 \\
2 & $8.98 \times 10^{5}$ & $5.31 \times 10^{5}$ & 59.18 \\
3 & $9.62 \times 10^{5}$ & $1.97 \times 10^{5}$ & 20.46 \\
4 & $4.03 \times 10^{5}$ & $2.43 \times 10^{5}$ & 60.13 \\
Average & $1.65 \times 10^{5}$ & $8.86 \times 10^{5}$ & 48.52 \\
sd & $1.59 \times 10^{5}$ & $1.04 \times 10^{5}$ & 18.88 \\
\hline
\end{tabular}

The next step consists of employing this human organ segment model to transfer a human gene of clinical interest for treating disease. With this purpose in mind, we used the previously reported conditions to transfer the human $A A T$ gene to human liver and evaluate its decoding efficiency in its target tissue. Aiming to completely differentiate between the protein encoded by the transferred gene and the endogenous AAT protein (with high rates of liver production), special gene constructs bearing an additional tracer (tag/flag) sequence of DNA with the ability to be transcribed and translated into synthetic mRNA and protein were required. In this regard, we have designed and constructed a plasmid containing the entire $h A A T$ gene with a flag sequence (hAAT-flag) presenting an open reading frame to permit its transcription and translation. We have already conducted preliminary studies in four human liver segments, injecting this AAT gene plasmid containing the flag sequence (hAAT-flag), under the conditions used in other studies. After gene transfer, tissue samples were cultured at $37^{\circ}$ under a 5\% CO2 atmosphere in DMEM medium. The analyses of the gene decoding process showed efficient expression of hAAT-flag protein in liver tissue (Table 5). The amount of tagged protein (AAT-flag) accounted for close to 50\% of total tissue AAT three days after gene transfer. This result proves that both endogenous and exogenous proteins were expressed with similar efficacy and that consequently the relative expression efficacy of exogenous protein is $100 \%$ when compared with the endogenous protein. This demonstrates that the hydrofection procedure could mediate efficacious protein expression after exogenous gene transfer in humans. The efficacy of protein export into the bloodstream from liver in order to exert systemic effects remains to be elucidated and further experiments and models would be required. 
Table 5. Hydrodynamic gene transfer works performed in human models. The table shows the author of each work, the publication year, the human model studied, the target cell or organ assayed, gene and gene construction, injection methodology, variables evaluated, disease of interest and effect duration.

\begin{tabular}{|c|c|c|c|c|c|c|c|c|c|}
\hline Author & Year & Model & Organ/Cell & Gene & Gene Construct & Methodology & Variables & Disease & $\begin{array}{l}\text { Long-Term } \\
\text { Expression }\end{array}$ \\
\hline Guillem, V [150] & 2002 & Human & $\begin{array}{l}\text { Lymphoid } \\
\text { cell line }\end{array}$ & ODN-FITC & CD3-PEI/ODN- & In vitro & $\begin{array}{l}\text { Fluorescence, } \\
\text { Cells increase }\end{array}$ & Method & \\
\hline Guillem, V [151] & 2002 & Human & $\begin{array}{l}\text { Jurkat \& } \\
\text { Granta }\end{array}$ & eGFP & CD3-PEI/eGFP & In vitro & Selective gene delivery & Method & \\
\hline Lledo, S [152] & 2005 & Human & $\begin{array}{l}\text { Cell line } \\
\text { SW480 }\end{array}$ & ASO-Kras & ASO phosphorotioates & In vitro & Cell viability & Cancer: colorectal & $72 \mathrm{~h}$ \\
\hline Lee, S [76] & 2008 & mouse/human cell & Liver & PTH & Plasmid DNA & $\mathrm{HD}$ & $\begin{array}{l}\text { Plasma protein, } \\
\text { expression }\end{array}$ & Hypoparathyroidism & \\
\hline Diaz-Moscoso, A [153] & 2011 & Human, Mouse & Macrophage & & $\begin{array}{c}80 \mathrm{~nm} \text { manosilted } \\
\text { cyclodextrin/DNAplex }\end{array}$ & In vitro & Delivery, FACS & & \\
\hline Doherty, J [85] & 2012 & Mouse/Human cell & $\begin{array}{l}\text { Liver/HEK293, } \\
\text { HeLa, T cells }\end{array}$ & $\begin{array}{c}\text { Neomycin } \\
\text { resistance cassette }\end{array}$ & transposone-piggybac & $\mathrm{HD}$ & Transgene expression & & 6 months \\
\hline Herrero, MJ [145] & 2012 & Human & Liver & eGFP & pCMV & $\mathrm{HD}$ & $\begin{array}{l}\text { Expression, } \mathrm{PCR}, \\
\text { fluorescence, IHC }\end{array}$ & & 2 days \\
\hline Taniyama, Y [154] & 2012 & Human & Heart & Various & Plasmid & $\begin{array}{l}\text { physical } \\
\text { procedures }\end{array}$ & & Various & \\
\hline Balbino, TA [155] & 2013 & Human cells & HeLa & & Cationic liposomes & $\begin{array}{l}\text { Microfluidic } \\
\text { systems } \\
\text { comparison }\end{array}$ & $\begin{array}{c}\text { Complex size, } \\
\text { non-electrostatic bond, } \\
\text { accessibility level }\end{array}$ & & \\
\hline Sevimli, S [156] & 2013 & Human & $\begin{array}{c}\text { Cells HepG2, } \\
\text { H460, } \\
\text { SHEP, MRC5 }\end{array}$ & GFP & $\begin{array}{l}\text { Anionic and cationic } \\
\text { polymers-siRNA }\end{array}$ & Transfection & $\begin{array}{l}\text { Diameter, potential, } \\
\text { stability, qPCR, WB, flow } \\
\text { cytometry, confocal }\end{array}$ & & \\
\hline Matsui, H [36] & 2014 & Mouse/Human cell & Liver/HEK293 & $\begin{array}{l}\text { Full length } \\
\text { Factor VIII }\end{array}$ & $\begin{array}{l}\text { Piggybac Transposon } \\
\text { Vector cDNA }\end{array}$ & $\mathrm{HD}$ & $\begin{array}{l}\text { Expression, } \mathrm{PCR}, \mathrm{qPCR}, \\
\text { Coagulation assays }\end{array}$ & Haemophilia A & $>300$ days \\
\hline Heller, R [157] & 2015 & Human & Various & Various & Non-viral & Electroporation & Clinical trials & Various & \\
\hline Mendrek, B [158] & 2015 & Human & $\begin{array}{c}\text { Cell line } \\
\text { HT1080 } \\
\text { (fibrosarcoma) }\end{array}$ & & Plasmid-polyplex & $\begin{array}{c}\text { Polyplexes } \\
\text { DMAEMA (+) vs. } \\
\text { DEGMA (0) }\end{array}$ & $\begin{array}{l}\text { Hydrodynamic size, } z \\
\text { potential, cytotoxicity, } \\
\text { transfection efficacy }\end{array}$ & & \\
\hline
\end{tabular}




\subsection{Future Perspectives: Isolated Organ with Continuous Vascular Perfusion and CRISPR Gene Edition}

Hydrodynamic liver gene therapy offers the possibility of treating systemic disorders due to the capacity of the liver to produce and release proteins into the bloodstream. Thus, a new model allowing the study not only of decoding but also of export should be developed. An isolated organ model with vascular perfusion and the possibility of keeping an entire human liver viable for a few days should allow us to evaluate the entire decoding process after hydrofection, from delivery to protein translation and export into the circulating medium. At present, different devices for maintaining liver circulation ex vivo are being used in the field of liver transplantation, such as Organox ${ }^{\circledR}$ and other experimental systems have been proposed [159]. Our group has already designed and constructed a preliminary system offering the possibility of liver maintenance for up to two days for preclinical studies. The hAAT-flag plasmid could be used in human livers connected to a continuous perfusion machine, with evaluation of the secretion of a human exogenous protein by the human liver. Efficient expression and secretion of hAAT-flag protein in perfusion medium could constitute the last step in the translational process prior to use in a clinical trial.

Hydrodynamic procedure for gene transfer has normally been used for naked DNA transfection. However, this strategy could facilitate the delivery of other gene constructs containing viral and non-viral vectors. Hydrofection would permit overcoming the main limitation of the different strategies for genome editing or repair (Zinc fingers, TALENS). In recent years, a new strategy (CRISPR/Cas9) for genome editing in a customized and inexpensive manner has emerged $[129,130]$ and this technology is reaching many laboratories. Although is an efficient strategy for targeted genome edition, a number of limitations must be resolved-fundamentally the difficulty of delivery to target cells and/or organs. The great appearance of CRISPR/Cas9 and its wide application throughout the world gave a renewed interest to hydrodynamic gene transfer methodology. The hydrodynamic gene transfer could mediate the delivery of CRISPR/Cas9 constructs in vivo, both as plasmid and as ribonucleoprotein complex, as a safe and efficient procedure of transfection.

Acknowledgments: This work has been partially supported by funding from Spanish Ministry of Economy and Competitiveness (SAF-2011-27002) and GRIFOLS SA ALTA Award 2017.

Conflicts of Interest: The authors declare no conflict of interest.

\section{References}

1. Aliño, S.F.; Crespo, J.; Bobadilla, M.; Lejarreta, M.; Blaya, C.; Crespo, A. Expression of human alpha 1-antitrypsin in mouse after in vivo gene transfer to hepatocytes by small liposomes. Biochem. Biophys. Res. Commun. 1994, 204, 1023-1030. [CrossRef]

2. Crepso, J. Long-term expression of the human alpha1-antitrypsin gene in mice employing anionic and cationic liposome vectors. Biochem. Pharmacol. 1996, 51, 1309-1314.

3. Dasí, F.; Benet, M.; Crespo, J.; Crespo, A.; Aliño, S.F. Asialofetuin liposome-mediated human alpha1-antitrypsin gene transfer in vivo results in stationary long-term gene expression. J. Mol. Med. 2001, 79, 205-212. [CrossRef]

4. Zhang, G.; Song, Y.K.; Liu, D. Long-term expression of human alpha1-antitrypsin gene in mouse liver achieved by intravenous administration of plasmid DNA using a hydrodynamics-based procedure. Gene Ther. 2000, 7, 1344-1349. [CrossRef]

5. Alino, S.F.; Crespo, A.; Dasi, F. Long-term therapeutic levels of human alpha-1 antitrypsin in plasma after hydrodynamic injection of nonviral DNA. Gene Ther. 2003, 10, 1672-1679. [CrossRef]

6. Wolff, J.A.; Malone, R.W.; Williams, P.; Chong, W.; Acsadi, G.; Jani, A.; Felgner, P.L. Direct gene transfer into mouse muscle in vivo. Science 1990, 247, 1465-1468. [CrossRef]

7. Budker, V.; Zhang, G.; Knechtle, S.; Wolff, J.A. Naked DNA delivered intraportally expresses efficiently in hepatocytes. Gene Ther. 1996, 3, 593-598.

8. Budker, V.; Zhang, G.; Danko, I.; Williams, P.; Wolff, J. The efficient expression of intravascularly delivered DNA in rat muscle. Gene Ther. 1998, 5, 272-276. [CrossRef]

9. Liu, F.; Song, Y.; Liu, D. Hydrodynamics-based transfection in animals by systemic administration of plasmid DNA. Gene Ther. 1999, 6, 1258-1266. [CrossRef] 
10. Gao, M.; Zhang, C.; Ma, Y.; Bu, L.; Yan, L.; Liu, D. Hydrodynamic delivery of mIL10 gene protects mice from high-fat diet-induced obesity and glucose intolerance. Mol. Ther. 2013, 21, 1852-1861. [CrossRef]

11. Gao, M.; Ma, Y.; Cui, R.; Liu, D. Hydrodynamic delivery of FGF21 gene alleviates obesity and fatty liver in mice fed a high-fat diet. J. Control. Release 2014, 185, 1-11. [CrossRef]

12. Ma, Y.; Gao, M.; Sun, H.; Liu, D. Interleukin-6 gene transfer reverses body weight gain and fatty liver in obese mice. Biochim. Biophys. Acta 2015, 1852, 1001-1011. [CrossRef]

13. Hamar, P.; Song, E.; Kökény, G.; Chen, A.; Ouyang, N.; Lieberman, J. Small interfering RNA targeting Fas protects mice against renal ischemia-reperfusion injury. Proc. Natl. Acad. Sci. USA 2004, 101, 14883-14888. [CrossRef]

14. Zhang, G.; Budker, V.; Williams, P.; Subbotin, V.; Wolff, J.A. Efficient expression of naked DNA delivered intraarterially to limb muscles of nonhuman primates. Hum. Gene Ther. 2001, 12, 427-438. [CrossRef]

15. Zhang, G.; Ludtke, J.J.; Thioudellet, C.; Kleinpeter, P.; Antoniou, M.; Herweijer, H.; Braun, S.; Wolff, J.A. Intraarterial delivery of naked plasmid DNA expressing full-length mouse dystrophin in the mdx mouse model of duchenne muscular dystrophy. Hum. Gene Ther. 2004, 15, 770-782. [CrossRef]

16. Mann, M.J.; Gibbons, G.H.; Hutchinson, H.; Poston, R.S.; Hoyt, E.G.; Robbins, R.C.; Dzau, V.J. Pressure-mediated oligonucleotide transfection of rat and human cardiovascular tissues. Proc. Natl. Acad. Sci. USA 1999, 96, 6411-6416. [CrossRef]

17. Crespo, A.; Peydró, A.; Dasí, F.; Benet, M.; Calvete, J.J.; Revert, F.; Aliño, S.F. Hydrodynamic liver gene transfer mechanism involves transient sinusoidal blood stasis and massive hepatocyte endocytic vesicles. Gene Ther. 2005, 12, 927-935. [CrossRef]

18. Aliño, S.F.; José Herrero, M.; Bodi, V.; Noguera, I.; Mainar, L.; Dasí, F.; Sempere, A.; Sánchez, M.; Díaz, A.; Sabater, L.; et al. Naked DNA delivery to whole pig cardiac tissue by coronary sinus retrograde injection employing non-invasive catheterization. J. Gene Med. 2010, 12, 920-926. [CrossRef]

19. Sendra, L.; Pérez, D.; Miguel, A.; Herrero, M.J.; Noguera, I.; Díaz, A.; Barettino, D.; Martí-Bonmatí, L.; Aliño, S.F. Human AAT gene transfer to pig liver improved by using a perfusion isolated organ endovascular procedure. Eur. Radiol. 2016, 26, 95-102. [CrossRef]

20. Jacobs, F.; Wisse, E.; De Geest, B. The role of liver sinusoidal cells in hepatocyte-directed gene transfer. Am. J. Pathol. 2010, 176, 14-21. [CrossRef]

21. Sendra, L.; Miguel, A.; Pérez-Enguix, D.; Herrero, M.J.; Montalvá, E.; García-Gimeno, M.A.; Noguera, I.; Díaz, A.; Pérez, J.; Sanz, P.; et al. Studying Closed Hydrodynamic Models of “In Vivo” DNA Perfusion in Pig Liver for Gene Therapy Translation to Humans. PLoS ONE 2016, 11, e0163898. [CrossRef]

22. Zhang, G.; Wooddell, C.I.; Hegge, J.O.; Griffin, J.B.; Huss, T.; Braun, S.; Wolff, J.A. Functional efficacy of dystrophin expression from plasmids delivered to $\mathrm{mdx}$ mice by hydrodynamic limb vein injection. Hum. Gene Ther. 2010, 21, 221-237. [CrossRef]

23. Zhang, G.; Marshall, A.L.; Thomas, A.L.; Kernan, K.A.; Su, Y.; LeBoeuf, R.C.; Dong, X.R.; Tchao, B.N. In vivo knockdown of nicotinic acetylcholine receptor alpha1 diminishes aortic atherosclerosis. Atherosclerosis 2011, 215, 34-42. [CrossRef]

24. Boström, P.; Wu, J.; Jedrychowski, M.P.; Korde, A.; Ye, L.; Lo, J.C.; Rasbach, K.A.; Boström, E.A.; Choi, J.H.; Long, J.Z.; et al. A PGC1-alpha-dependent myokine that drives brown-fat-like development of white fat and thermogenesis. Nature 2012, 481, 463-468. [CrossRef]

25. Guess, M.G.; Barthel, K.K.; Pugach, E.K.; Leslie, A. Measuring microRNA reporter activity in skeletal muscle using hydrodynamic limb vein injection of plasmid DNA combined with in vivo imaging. Skelet Muscle 2013, 3, 19. [CrossRef]

26. Mukumoto, H.; Takahashi, Y.; Ando, M.; Nishikawa, M.; Takakura, Y. Expression profile-dependent improvement of insulin sensitivity by gene delivery of interleukin-6 in a mouse model of type II diabetes. Mol. Pharm. 2013, 10, 3812-3821. [CrossRef]

27. Nagata, K.; Itaka, K.; Baba, M.; Uchida, S.; Ishii, T.; Kataoka, K. Muscle-targeted hydrodynamic gene introduction of insulin-like growth factor-1 using polyplex nanomicelle to treat peripheral nerve injury. J. Control. Release 2014, 183, 27-34. [CrossRef]

28. Aliño, S.F.; Bobadilla, M.; Garcia-Sanz, M.; Lejarreta, M.; Unda, F.; Hilario, E. In vivo delivery of human alpha 1-antitrypsin gene to mouse hepatocytes by liposomes. Biochem. Biophys. Res. Commun. 1993, 192, 174-181. [CrossRef] 
29. Aliño, S.F.; Bobadilla, M.; Crespo, J.; Lejarreta, M. Human alpha 1-antitrypsin gene transfer to in vivo mouse hepatocytes. Hum. Gene Ther. 1996, 7, 531-536. [CrossRef]

30. Zhang, G.; Budker, V.; Wolff, J.A. High levels of foreign gene expression in hepatocytes after tail vein injections of naked plasmid DNA. Hum. Gene Ther. 1999, 10, 1735-1737. [CrossRef]

31. Herrero, M.J.; Monleon, D.; Morales, J.M.; Mata, M.; Serna, E.; Aliño, S.F. Analysis of metabolic and gene expression changes after hydrodynamic DNA injection into mouse liver. Biol. Pharm. Bull. 2011, 34, 167-172. [CrossRef]

32. Schüttrumpf, J.; Milanov, P.; Roth, S.; Seifried, E.; Tonn, T. Non-viral gene transfer results in therapeutic factor IX levels in haemophilia B mice. Hamostaseologie 2008, 28 (Suppl. 1), S92-S95.

33. Keravala, A.; Chavez, C.L.; Hu, G.; Woodard, L.E.; Monahan, P.E.; Calos, M.P. Long-term phenotypic correction in factor IX knockout mice by using PhiC31 integrase-mediated gene therapy. Gene Ther. 2011, 18, 842-848. [CrossRef]

34. Kim, H.S.; Kim, J.C.; Lee, Y.K.; Kim, J.S.; Park, Y.S. Hepatic control elements promote long-term expression of human coagulation factor IX gene in hydrodynamically transfected mice. J. Gene Med. 2011, 13, 365-372. [CrossRef] [PubMed]

35. Schüttrumpf, J.; Milanov, P.; Abriss, D.; Roth, S.; Tonn, T.; Seifried, E. Transgene loss and changes in the promoter methylation status as determinants for expression duration in nonviral gene transfer for factor IX. Hum. Gene Ther. 2011, 22, 101-106. [CrossRef]

36. Matsui, H.; Fujimoto, N.; Sasakawa, N.; Ohinata, Y.; Shima, M.; Yamanaka, S.; Sugimoto, M.; Hotta, A. Delivery of full-length factor VIII using a piggyBac transposon vector to correct a mouse model of hemophilia A. PLoS ONE 2014, 9, e104957. [CrossRef]

37. Holm, D.A.; Dagnaes-Hansen, F.; Simonsen, H.; Gregersen, N.; Bolund, L.; Jensen, T.G.; Corydon, T.J. Expression of short-chain acyl-CoA dehydrogenase (SCAD) proteins in the liver of SCAD deficient mice after hydrodynamic gene transfer. Mol. Genet. Metab. 2003, 78, 250-258. [CrossRef]

38. Turunen, T.A.; Kurkipuro, J.; Heikura, T.; Vuorio, T.; Hytönen, E.; Izsvák, Z.; Ylä-Herttuala, S. Sleeping Beauty Transposon Vectors in Liver-directed Gene Delivery of LDLR and VLDLR for Gene Therapy of Familial Hypercholesterolemia. Mol. Ther. 2016, 24, 620-635. [CrossRef]

39. Jiang, J.; Yamato, E.; Miyazaki, J. Long-term control of food intake and body weight by hydrodynamics-based delivery of plasmid DNA encoding leptin or CNTF. J. Gene Med. 2003, 5, 977-983. [CrossRef]

40. González-Muniesa, P.; Milagro, F.I.; Campión, J.; Martínez, J.A. Reduction in energy efficiency induced by expression of the uncoupling protein, UCP1, in mouse liver mitochondria. Int. J. Mol. Med. 2006, 17, 591-597. [CrossRef]

41. He, C.X.; Shi, D.; Wu, W.J.; Ding, Y.F.; Feng, D.M.; Lu, B.; Chen, H.M.; Yao, J.H.; Shen, Q.; Lu, D.R.; et al. Insulin expression in livers of diabetic mice mediated by hydrodynamics-based administration. World J. Gastroenterol. 2004, 10, 567-572. [CrossRef]

42. Fukushima, M.; Hattori, Y.; Tsukada, H.; Koga, K.; Kajiwara, E.; Kawano, K.; Kobayashi, T.; Kamata, K.; Maitani, Y. Adiponectin gene therapy of streptozotocin-induced diabetic mice using hydrodynamic injection. J. Gene Med. 2007, 9, 976-985. [CrossRef]

43. Ma, Y.; Liu, D. Hydrodynamic delivery of adiponectin and adiponectin receptor 2 gene blocks high-fat diet-induced obesity and insulin resistance. Gene Ther. 2013, 20, 846-852. [CrossRef]

44. Vakili, S.; Ebrahimi, S.S.; Sadeghi, A.; Gorgani-Firuzjaee, S.; Beigy, M.; Pasalar, P.; Meshkani, R. Hydrodynamicbased delivery of PTP1B shRNA reduces plasma glucose levels in diabetic mice. Mol. Med. Rep. 2013, 7, 211-216. [CrossRef]

45. Baribault, H.; Majeti, J.Z.; Ge, H.; Wang, J.; Xiong, Y.; Gardner, J.; Yang, L.; Gupte, J.; Gong, Y.; Pan, Z.; et al. Advancing therapeutic discovery through phenotypic screening of the extracellular proteome using hydrodynamic intravascular injection. Expert. Opin. Ther. Targets 2014, 18, 1253-1264. [CrossRef] [PubMed]

46. Camassola, M.; Braga, L.M.; Delgado-Cañedo, A.; Dalberto, T.P.; Matte, U.; Burin, M.; Giugliani, R.; Nardi, N.B. Nonviral in vivo gene transfer in the mucopolysaccharidosis I murine model. J. Inherit. Metab. Dis. 2005, 28, 1035-1043. [CrossRef]

47. Richard, M.; Arfi, A.; Seguin, J.; Gandolphe, C.; Scherman, D. Widespread biochemical correction of murine mucopolysaccharidosis type VII pathology by liver hydrodynamic plasmid delivery. Gene Ther. 2009, 16, 746-756. [CrossRef] 
48. Quiviger, M.; Arfi, A.; Mansard, D.; Delacotte, L.; Pastor, M.; Scherman, D.; Marie, C. High and prolonged sulfamidase secretion by the liver of MPS-IIIA mice following hydrodynamic tail vein delivery of antibiotic-free pFAR4 plasmid vector. Gene Ther. 2014, 21, 1001-1007. [CrossRef]

49. Pergolizzi, R.G.; Jin, G.; Chan, D.; Pierre, L.; Bussel, J.; Ferris, B.; Leopold, P.L.; Crystal, R.G. Correction of a murine model of von Willebrand disease by gene transfer. Blood 2006, 108, 862-869. [CrossRef]

50. Belcher, J.D.; Vineyard, J.V.; Bruzzone, C.M.; Chen, C.; Beckman, J.D.; Nguyen, J.; Steer, C.J.; Vercellotti, G.M. Heme oxygenase-1 gene delivery by Sleeping Beauty inhibits vascular stasis in a murine model of sickle cell disease. J. Mol. Med. 2010, 88, 665-675. [CrossRef]

51. Viecelli, H.M.; Harbottle, R.P.; Wong, S.P.; Schlegel, A.; Chuah, M.K.; VandenDriessche, T.; Harding, C.O.; Thöny, B. Treatment of phenylketonuria using minicircle-based naked-DNA gene transfer to murine liver. Hepatology 2014, 60, 1035-1043. [CrossRef]

52. Grisch-Chan, H.M.; Schlegel, A.; Scherer, T.; Allegri, G.; Heidelberger, R.; Tsikrika, P.; Schmeer, M.; Schleef, M.; Harding, C.O.; Häberle, J.; et al. Low-Dose Gene Therapy for Murine PKU Using Episomal Naked DNA Vectors Expressing PAH from Its Endogenous Liver Promoter. Mol. Ther. Nucleic Acids 2017, 7, 339-349. [CrossRef]

53. Yang, P.L.; Althage, A.; Chung, J.; Chisari, F.V. Hydrodynamic injection of viral DNA: a mouse model of acute hepatitis B virus infection. Proc. Natl. Acad. Sci. USA 2002, 99, 13825-13830. [CrossRef]

54. McCaffrey, A.P.; Ohashi, K.; Meuse, L.; Shen, S.; Lancaster, A.M.; Lukavsky, P.J.; Sarnow, P.; Kay, M.A. Determinants of hepatitis $C$ translational initiation in vitro, in cultured cells and mice. Mol. Ther. 2002, 5, 676-684. [CrossRef]

55. Kim, S.I.; Shin, D.; Lee, H.; Ahn, B.Y.; Yoon, Y.; Kim, M. Targeted delivery of siRNA against hepatitis C virus by apolipoprotein A-I-bound cationic liposomes. J. Hepatol. 2009, 50, 479-488. [CrossRef]

56. Zender, L.; Hutker, S.; Liedtke, C.; Tillmann, H.L.; Zender, S.; Mundt, B.; Waltemathe, M.; Gosling, T.; Flemming, P.; Malek, N.P.; et al. Caspase 8 small interfering RNA prevents acute liver failure in mice. Proc. Natl. Acad. Sci. USA 2003, 100, 7797-7802. [CrossRef]

57. Saito, Y.; Kon, S.; Fujiwara, Y.; Nakayama, Y.; Kurotaki, D.; Fukuda, N.; Kimura, C.; Kanayama, M.; Ito, K.; Diao, H.; et al. Osteopontin small interfering RNA protects mice from fulminant hepatitis. Hum. Gene Ther. 2007, 18, 1205-1214. [CrossRef]

58. Xu, J.F.; Xiao, H.; Hu, G.Y.; Zheng, S.H.; Liu, W.; Yuan, C.L.; Yang, H.; Lü, J.; Zheng, F.; Wang, C.Y.; et al. Ectopic B7-H4-Ig expression attenuates concanavalin A-induced hepatic injury. Clin. Immunol. 2010, 136, 30-41. [CrossRef]

59. Bulau, A.-M.; Fink, M.; Maucksch, C.; Kappler, R.; Mayr, D.; Wagner, K.; Bufler, P. In vivo expression of interleukin-37 reduces local and systemic inflammation in concanavalin A-induced hepatitis. ScientificWorldJournal 2011, 11, 2480-2490. [CrossRef]

60. Shashidharamurthy, R.; Machiah, D.; Bozeman, E.N.; Srivatsan, S.; Patel, J.; Cho, A.; Jacob, J.; Selvaraj, P. Hydrodynamic delivery of plasmid DNA encoding human FcgammaR-Ig dimers blocks immune-complex mediated inflammation in mice. Gene Ther. 2012, 19, 877-885. [CrossRef]

61. Anavi, S.; Hahn-Obercyger, M.; Margalit, R.; Madar, Z.; Tirosh, O. A novel antihypoglycemic role of inducible nitric oxide synthase in liver inflammatory response induced by dietary cholesterol and endotoxemia. Antioxid. Redox Signal. 2013, 19, 1889-1901. [CrossRef]

62. Huang, M.; Sun, R.; Wei, H.; Tian, Z. Simultaneous knockdown of multiple ligands of innate receptor NKG2D prevents natural killer cell-mediated fulminant hepatitis in mice. Hepatology 2013, 57, 277-288. [CrossRef]

63. Görtz, D.; Braun, G.S.; Maruta, Y.; Djudjaj, S.; van Roeyen, C.R.; Martin, I.V.; Küster, A.; Schmitz-Van de Leur, H.; Scheller, J.; Ostendorf, T.; et al. Anti-interleukin-6 therapy through application of a monogenic protein inhibitor via gene delivery. Sci. Rep. 2015, 5, 14685. [CrossRef]

64. Tsai, S.M.; Wang, W.P. Expression and function of fibroblast growth factor (FGF) 7 during liver regeneration. Cell. Physiol. Biochem. 2011, 27, 641-652. [CrossRef]

65. Wu, X.; He, Y.; Falo, L.D., Jr.; Hui, K.M.; Huang, L. Regression of human mammary adenocarcinoma by systemic administration of a recombinant gene encoding the hFlex-TRAIL fusion protein. Mol. Ther. 2001, 3, 368-374. [CrossRef]

66. Yazawa, H.; Murakami, T.; Li, H.M.; Back, T.; Kurosaka, K.; Suzuki, Y.; Shorts, L.; Akiyama, Y.; Maruyama, K.; Parsoneault, E.; et al. Hydrodynamics-based gene delivery of naked DNA encoding fetal liver kinase-1 gene effectively suppresses the growth of pre-existing tumors. Cancer Gene Ther. 2006, 13, 993-1001. [CrossRef] 
67. Miyakawa, N.; Nishikawa, M.; Takahashi, Y.; Ando, M.; Misaka, M.; Watanabe, Y.; Takakura, Y. Prolonged circulation half-life of interferon gamma activity by gene delivery of interferon gamma-serum albumin fusion protein in mice. J. Pharm. Sci. 2011, 100, 2350-2357. [CrossRef]

68. Ando, M.; Takahashi, Y.; Nishikawa, M.; Takakura, Y. Control of spatiotemporal distribution of interferon gamma by genetically fusing functional peptides. Yakugaku Zasshi 2012, 132, 1399-1406. [CrossRef]

69. Miyakawa, N.; Nishikawa, M.; Takahashi, Y.; Ando, M.; Misaka, M.; Watanabe, Y.; Takakura, Y. Gene delivery of albumin binding peptide-interferon-gamma fusion protein with improved pharmacokinetic properties and sustained biological activity. J. Pharm. Sci. 2013, 102, 3110-3118. [CrossRef]

70. Ando, M.; Takahashi, Y.; Yamashita, T.; Fujimoto, M.; Nishikawa, M.; Watanabe, Y.; Takakura, Y. Prevention of adverse events of interferon gamma gene therapy by gene delivery of interferon gamma-heparin-binding domain fusion protein in mice. Mol. Ther. Methods Clin. Dev. 2014, 1, 14023. [CrossRef]

71. Ochoa, M.C.; Fioravanti, J.; Duitman, E.H.; Medina-Echeverz, J.; Palazon, A.; Arina, A.; Dubrot, J.; Alfaro, C.; Morales-Kastresana, A.; Murillo, O.; et al. Liver gene transfer of interkeukin-15 constructs that become part of circulating high density lipoproteins for immunotherapy. PLoS ONE 2012, 7, e52370. [CrossRef]

72. Barao, I.; Alvarez, M.; Redelman, D.; Weiss, J.M.; Ortaldo, J.R.; Wiltrout, R.H.; Murphy, W.J. Hydrodynamic delivery of human IL-15 cDNA increases murine natural killer cell recovery after syngeneic bone marrow transplantation. Biol. Blood Marrow Transplant. 2011, 17, 1754-1764. [CrossRef] [PubMed]

73. Sun, H.; Liu, D. IL-15/sIL-15Ralpha gene transfer suppresses Lewis lung cancer growth in the lungs, liver and kidneys. Cancer Gene Ther. 2016, 23, 54-60. [CrossRef]

74. Qiu, C.; Li, Y.; Zhou, M.; Liu, J.; Li, M.; Wu, Y.; Xu, D.; Li, M. Hydrodynamic delivery of IL-28B (IFN-lambda3) gene ameliorates lung inflammation induced by cigarette smoke exposure in mice. Biochem. Biophys. Res. Commun. 2014, 447, 513-519. [CrossRef]

75. Sondergaard, M.; Dagnaes-Hansen, F.; Flyvbjerg, A.; Jensen, T.G. Normalization of growth in hypophysectomized mice using hydrodynamic transfer of the human growth hormone gene. Am. J. Physiol. Endocrinol. Metab. 2003, 285, E427-E432. [CrossRef]

76. Lee, S.; Hong, S.W.; Choi, H.S.; Lee, L.Y.; Nam, C.; Rhee, Y.; Chung, U.-I.; Lim, S.-K. Experimental parathyroid hormone gene therapy using OC31 integrase. Endocr. J. 2008, 55, 1033-1041. [CrossRef]

77. Okumura, A.; Saito, T.; Otani, I.; Kojima, K.; Yamada, Y.; Ishida-Okawara, A.; Nakazato, K.; Asano, M.; Kanayama, K.; Iwakura, Y.; et al. Suppressive role of leukocyte cell-derived chemotaxin 2 in mouse anti-type II collagen antibody-induced arthritis. Arthritis Rheum. 2008, 58, 413-421. [CrossRef]

78. Watcharanurak, K.; Nishikawa, M.; Takahashi, Y.; Kabashima, K.; Takahashi, R.; Takakura, Y. Regulation of immunological balance by sustained interferon-gamma gene transfer for acute phase of atopic dermatitis in mice. Gene Ther. 2013, 20, 538-544. [CrossRef]

79. Wesche-Soldato, D.E.; Chung, C.S.; Lomas-Neira, J.; Doughty, L.A.; Gregory, S.H.; Ayala, A. In vivo delivery of caspase-8 or Fas siRNA improves the survival of septic mice. Blood 2005, 106, 2295-2301. [CrossRef] [PubMed]

80. Tompkins, S.M.; Lo, C.Y.; Tumpey, T.M.; Epstein, S.L. Protection against lethal influenza virus challenge by RNA interference in vivo. Proc. Natl. Acad. Sci. USA 2004, 101, 8682-8686. [CrossRef]

81. Lu, S.L.; Tsai, C.Y.; Luo, Y.H.; Kuo, C.F.; Lin, W.C.; Chang, Y.T.; Wu, J.J.; Chuang, W.J.; Liu, C.C.; Chao, L.; et al. Kallistatin modulates immune cells and confers anti-inflammatory response to protect mice from group A streptococcal infection. Antimicrob. Agents Chemother. 2013, 57, 5366-5372. [CrossRef]

82. Nakamura, G.; Maruyama, H.; Ishii, S.; Shimotori, M.; Kameda, S.; Kono, T.; Miyazaki, J.; Kulkarni, A.B.; Gejyo, F. Naked plasmid DNA-based alpha-galactosidase A gene transfer partially reduces systemic accumulation of globotriaosylceramide in Fabry mice. Mol. Biotechnol. 2008, 38, 109-119. [CrossRef]

83. Bell, J.B.; Podetz-Pedersen, K.M.; Aronovich, E.L.; Belur, L.R.; McIvor, R.S.; Hackett, P.B. Preferential delivery of the Sleeping Beauty transposon system to livers of mice by hydrodynamic injection. Nat. Protoc. 2007, 2, 3153-3165. [CrossRef]

84. Hackett, P.B., Jr.; Aronovich, E.L.; Hunter, D.; Urness, M.; Bell, J.B.; Kass, S.J.; Cooper, L.J.; McIvor, S. Efficacy and safety of Sleeping Beauty transposon-mediated gene transfer in preclinical animal studies. Curr. Gene Ther. 2011, 11,341-349. [CrossRef]

85. Doherty, J.E.; Huye, L.E.; Yusa, K.; Zhou, L.; Craig, N.L.; Wilson, M.H. Hyperactive piggyBac gene transfer in human cells and in vivo. Hum. Gene Ther. 2012, 23, 311-320. [CrossRef] 
86. Chen, I.Y.; Paulmurugan, R.; Nielsen, C.H.; Wang, D.S.; Chow, V.; Robbins, R.C.; Gambhir, S.S. A titratable two-step transcriptional amplification strategy for targeted gene therapy based on ligand-induced intramolecular folding of a mutant human estrogen receptor. Mol. Imaging Biol. 2014, 16, 224-234. [CrossRef]

87. Chu, Q.; Joseph, M.; Przybylska, M.; Yew, N.S.; Scheule, R.K. Transient siRNA-mediated attenuation of liver expression from an alpha-galactosidase A plasmid reduces subsequent humoral immune responses to the transgene product in mice. Mol. Ther. 2005, 12, 264-273. [CrossRef]

88. Wesche-Soldato, D.E.; Lomas-Neira, J.; Perl, M.; Chung, C.S.; Ayala, A. Hydrodynamic delivery of siRNA in a mouse model of sepsis. Methods Mol. Biol. 2008, 442, 67-73. [PubMed]

89. Magnusson, T.; Haase, R.; Schleef, M.; Wagner, E.; Ogris, M. Sustained, high transgene expression in liver with plasmid vectors using optimized promoter-enhancer combinations. J. Gene Med. 2011, 13, 382-391. [CrossRef]

90. Yan, S.; Fu, Q.; Zhou, Y.; Wang, J.; Liu, Y.; Duan, X.; Jia, S.; Peng, J.; Gao, B.; Du, J. High levels of gene expression in the hepatocytes of adult mice, neonatal mice and tree shrews via retro-orbital sinus hydrodynamic injections of naked plasmid DNA. J. Control. Release 2012, 161, 763-771. [CrossRef]

91. Shigekawa, M.; Hikita, H.; Kodama, T.; Shimizu, S.; Li, W.; Uemura, A.; Miyagi, T.; Hosui, A.; Kanto, T.; Hiramatsu, N. Pancreatic STAT3 protects mice against caerulein-induced pancreatitis via PAP1 induction. Am. J. Pathol. 2012, 181, 2105-2113. [CrossRef]

92. Dagnaes-Hansen, F.; Holst, H.U.; Søndergaard, M.; Vorup-Jensen, T.; Flyvbjerg, A.; Jensen, U.B.; Jensen, T.G. Physiological effects of human growth hormone produced after hydrodynamic gene transfer of a plasmid vector containing the human ubiquitin promotor. J. Mol. Med. 2002, 80, 665-670. [CrossRef]

93. Hagstrom, J.E.; Hegge, J.; Zhang, G.; Noble, M.; Budker, V.; Lewis, D.L.; Herweijer, H.; Wolff, J.A. A facile nonviral method for delivering genes and siRNAs to skeletal muscle of mammalian limbs. Mol. Ther. 2004, 10, 386-398. [CrossRef]

94. Zhang, G.; Gao, X.; Song, Y.K.; Vollmer, R.; Stolz, D.B.; Gasiorowski, J.Z.; Dean, D.A.; Liu, D. Hydroporation as the mechanism of hydrodynamic delivery. Gene Ther. 2004, 11, 675-682. [CrossRef]

95. Li, W.; Ma, N.; Ong, L.L.; Kaminski, A.; Skrabal, C.; Ugurlucan, M.; Lorenz, P.; Gatzen, H.H.; Lützow, K.; Lendlein, A. Enhanced thoracic gene delivery by magnetic nanobead-mediated vector. J. Gene Med. 2008, 10, 897-909. [CrossRef]

96. Suda, T.; Suda, K.; Liu, D. Computer-assisted hydrodynamic gene delivery. Mol. Ther. 2008, 16, 1098-1104. [CrossRef]

97. Podetz-Pedersen, K.M.; Bell, J.B.; Steele, T.W.; Wilber, A.; Shier, W.T.; Belur, L.R.; McIvor, R.S.; Hackett, P.B. Gene expression in lung and liver after intravenous infusion of polyethylenimine complexes of Sleeping Beauty transposons. Hum. Gene Ther. 2010, 21, 210-220. [CrossRef]

98. Wooddell, C.I.; Hegge, J.O.; Zhang, G.; Sebestyen, M.G.; Noble, M.; Griffin, J.B.; Pfannes, L.V.; Herweijer, H.; Hagstrom, J.E.; Braun, S.; et al. Dose response in rodents and nonhuman primates after hydrodynamic limb vein delivery of naked plasmid DNA. Hum. Gene Ther. 2011, 22, 889-903. [CrossRef]

99. Bu, X.; Zhou, Y.; Zhang, H.; Qiu, W.; Chen, L.; Cao, H.; Fang, L.; Wen, P.; Tan, R.; Yang, J. Systemic administration of naked plasmid encoding HGF attenuates puromycin aminonucleoside-induced damage of murine glomerular podocytes. Am. J. Physiol. Renal Physiol. 2011, 301, F784-F792. [CrossRef]

100. Duguid, J.G.; Li, C.; Shi, M.; Logan, M.J.; Alila, H.; Rolland, A.; Tomlinson, E.; Sparrow, J.T.; Smith, L.C. A physicochemical approach for predicting the effectiveness of peptide-based gene delivery systems for use in plasmid-based gene therapy. Biophys. J. 1998, 74, 2802-2814. [CrossRef]

101. Moret, I.; Esteban Peris, J.; Guillem, V.M.; Benet, M.; Revert, F.; Dasí, F.; Crespo, A.; Aliño, S.F. Stability of PEI-DNA and DOTAP-DNA complexes: effect of alkaline $\mathrm{pH}$, heparin and serum. J. Control. Release 2001, 76, 169-181. [CrossRef]

102. Alino, S.F.; Escriga, E.; Reverta, F.; Guillema, V.M.; Crespoa, A. Pharmacodynamic approach to study the gene transfer process employing non-viral vectors. Biochem. Pharmacol. 2000, 60, 1845-1853. [CrossRef]

103. Xu, Z.X.; Chen, J.Z.; Yue, Y.B.; Zhang, J.Q.; Li, Z.H.; Feng, D.M.; Ruan, Z.C.; Tian, L.; Xue, J.L.; Wang, Q.J. A 16-bp RBE element mediated Rep-dependent site-specific integration in AAVS1 transgenic mice for expression of hFIX. Gene Ther. 2009, 16, 589-595. [CrossRef]

104. Hibbitt, O.C.; Harbottle, R.P.; Waddington, S.N.; Bursill, C.A.; Coutelle, C.; Channon, K.M.; Wade-Martins, R. Delivery and long-term expression of a $135 \mathrm{~kb}$ LDLR genomic DNA locus in vivo by hydrodynamic tail vein injection. J. Gene Med. 2007, 9, 488-497. [CrossRef] 
105. Shahaf, G.; Moser, H.; Ozeri, E.; Mizrahi, M.; Abecassis, A.; Lewis, E.C. alpha-1-antitrypsin gene delivery reduces inflammation, increases T-regulatory cell population size and prevents islet allograft rejection. Mol. Med. 2011, 17, 1000-1011. [CrossRef]

106. Hibbitt, O.; Wade-Martins, R. High capacity extrachromosomal gene expression vectors. Methods Mol. Biol. 2011, 738, 19-40.

107. Wooddell, C.I.; Reppen, T.; Wolff, J.A.; Herweijer, H. Sustained liver-specific transgene expression from the albumin promoter in mice following hydrodynamic plasmid DNA delivery. J. Gene Med. 2008, 10, 551-563. [CrossRef]

108. Higuchi, N.; Maruyama, H.; Kuroda, T.; Kameda, S.; Iino, N.; Kawachi, H.; Nishikawa, Y.; Hanawa, H.; Tahara, H.; Miyazaki, J.; et al. Hydrodynamics-based delivery of the viral interleukin-10 gene suppresses experimental crescentic glomerulonephritis in Wistar-Kyoto rats. Gene Ther. 2003, 10, 1297-1310. [CrossRef]

109. Inoue, S.; Hakamata, Y.; Kaneko, M.; Kobayashi, E. Gene therapy for organ grafts using rapid injection of naked DNA: application to the rat liver. Transplantation 2004, 77, 997-1003. [CrossRef]

110. Miki, Y.; Maruyama, S.; Liu, D.; Kobayashi, T.; Sato, F.; Shimizu, H.; Kato, S.; Sato, W.; Morita, Y.; Yuzawa, Y. In vivo gene transfer of endo-beta-galactosidase $\mathrm{C}$ removes alphaGal antigen on erythrocytes and endothelial cells of the organs. Xenotransplantation 2004, 11, 444-451. [CrossRef]

111. Wang, C.H.; Liang, C.L.; Huang, L.T.; Liu, J.K.; Hung, P.H.; Sun, A.; Hung, K.S. Single intravenous injection of naked plasmid DNA encoding erythropoietin provides neuroprotection in hypoxia-ischemia rats. Biochem. Biophys. Res. Commun. 2004, 314, 1064-1071. [CrossRef]

112. Yokoi, H.; Mukoyama, M.; Nagae, T.; Mori, K.; Suganami, T.; Sawai, K.; Yoshioka, T.; Koshikawa, M.; Nishida, T.; Takigawa, M. Reduction in connective tissue growth factor by antisense treatment ameliorates renal tubulointerstitial fibrosis. J. Am. Soc. Nephrol. 2004, 15, 1430-1440. [CrossRef]

113. Zhang, X.; Dong, X.; Sawyer, G.J.; Collins, L.; Fabre, J.W. Regional hydrodynamic gene delivery to the rat liver with physiological volumes of DNA solution. J. Gene Med. 2004, 6, 693-703. [CrossRef]

114. Liu, H.; Hanawa, H.; Yoshida, T.; Elnaggar, R.; Hayashi, M.; Watanabe, R.; Toba, K.; Yoshida, K.; Chang, H.; Okura, Y. Effect of hydrodynamics-based gene delivery of plasmid DNA encoding interleukin-1 receptor antagonist-Ig for treatment of rat autoimmune myocarditis: possible mechanism for lymphocytes and noncardiac cells. Circulation 2005, 111, 1593-1600. [CrossRef]

115. Chang, H.; Hanawa, H.; Yoshida, T.; Hayashi, M.; Liu, H.; Ding, L.; Otaki, K.; Hao, K.; Yoshida, K.; Kato, K. Alteration of IL-17 related protein expressions in experimental autoimmune myocarditis inhibition of IL-17 by IL-10-Ig fusion gene transfer. Circ. J. 2008, 72, 813-819. [CrossRef]

116. Chang, H.; Wang, Y.; Li, G.; Zhang, L.; Zhang, G.W.; Liao, Y.C.; Hanawa, H.; Zou, J. Effect of hydrodynamics-based delivery of IL-18BP fusion gene on rat experimental autoimmune myocarditis. Clin. Exp. Med. 2014, 14, 397-408. [CrossRef]

117. Tsoulfas, G.; Takahashi, Y.; Liu, D.; Yagnik, G.; Wu, T.; Murase, N.; Geller, D.A. Hydrodynamic plasmid DNA gene therapy model in liver transplantation. J. Surg. Res. 2006, 135, 242-249. [CrossRef]

118. Chen, S.W.; Zhang, X.R.; Wang, C.Z.; Chen, W.Z.; Xie, W.F.; Chen, Y.X. RNA interference targeting the platelet-derived growth factor receptor beta subunit ameliorates experimental hepatic fibrosis in rats. Liver Int. 2008, 28, 1446-1457. [CrossRef]

119. Xing, Y.; Pua, E.C.; Lu, X.; Zhong, P. Low-amplitude ultrasound enhances hydrodynamic-based gene delivery to rat kidney. Biochem. Biophys. Res. Commun. 2009, 386, 217-222. [CrossRef]

120. Sawyer, G.J.; Zhang, X.; Fabre, J.W. Technical requirements for effective regional hydrodynamic gene delivery to the left lateral lobe of the rat liver. Gene Ther. 2010, 17, 560-564. [CrossRef]

121. Cim, A.; Sawyer, G.J.; Zhang, X.; Su, H.; Collins, L.; Jones, P.; Antoniou, M.; Reynes, J.P.; Lipps, H.J.; Fabre, J.W. In vivo studies on non-viral transdifferentiation of liver cells towards pancreatic beta cells. J. Endocrinol. 2012, 214, 277-288. [CrossRef]

122. Zhao, M.D.; Sun, Y.M.; Fu, G.F.; Du, Y.Z.; Chen, F.Y.; Yuan, H.; Zheng, C.H.; Zhang, X.M.; Hu, F.Q. Gene therapy of endometriosis introduced by polymeric micelles with glycolipid-like structure. Biomaterials 2012, 33, 634-643. [CrossRef] [PubMed]

123. Zhu, C.; Li, Y.; Li, W.; Wu, Q.; Gao, R. Gene transfer of c-met confers protection against D-galactosamine/ lipopolysaccharide-induced acute liver failure. Dig. Dis. Sci. 2012, 57, 925-934. [CrossRef] [PubMed]

124. Yasuzaki, Y.; Yamada, Y.; Kanefuji, T.; Harashima, H. Localization of exogenous DNA to mitochondria in skeletal muscle following hydrodynamic limb vein injection. J. Control. Release 2013, 172, 805-811. [CrossRef] 
125. Eastman, S.J.; Baskin, K.M.; Hodges, B.L.; Chu, Q.; Gates, A.; Dreusicke, R.; Anderson, S.; Scheule, R.K. Development of catheter-based procedures for transducing the isolated rabbit liver with plasmid DNA. Hum. Gene Ther. 2002, 13, 2065-2077. [CrossRef]

126. Kamimura, K.; Kanefuji, T.; Yokoo, T.; Abe, H.; Suda, T.; Kobayashi, Y.; Zhang, G.; Aoyagi, Y.; Liu, D. Safety assessment of liver-targeted hydrodynamic gene delivery in dogs. PLoS ONE 2014, 9, e107203. [CrossRef]

127. Yoshino, H.; Hashizume, K.; Kobayashi, E. Naked plasmid DNA transfer to the porcine liver using rapid injection with large volume. Gene Ther. 2006, 13, 1696-1702. [CrossRef]

128. Aliño, S.F.; Herrero, M.J.; Noguera, I.; Dasí, F.; Sánchez, M. Pig liver gene therapy by noninvasive interventionist catheterism. Gene Ther. 2007, 14, 334-343. [CrossRef]

129. Fabre, J.W.; Grehan, A.; Whitehorne, M.; Sawyer, G.J.; Dong, X.; Salehi, S.; Eckley, L.; Zhang, X.; Seddon, M.; Shah, A.M. Hydrodynamic gene delivery to the pig liver via an isolated segment of the inferior vena cava. Gene Ther. 2008, 15, 452-462. [CrossRef]

130. Kamimura, K.; Zhang, G.; Liu, D. Image-guided, intravascular hydrodynamic gene delivery to skeletal muscle in pigs. Mol. Ther. 2010, 18, 93-100. [CrossRef]

131. Fabre, J.W.; Whitehorne, M.; Grehan, A.; Sawyer, G.J.; Zhang, X.; Davenport, M.; Rela, M. Critical physiological and surgical considerations for hydrodynamic pressurization of individual segments of the pig liver. Hum. Gene Ther. 2011, 22, 879-887. [CrossRef]

132. Carreño, O.; Sendra, L.; Montalvá, E.; Miguel, A.; Orbis, F.; Herrero, M.J.; Noguera, I.; Aliño, S.F.; Lopez-Andujar, R. A surgical model for isolating the pig liver in vivo for gene therapy. Eur. Surg. Res. 2013, 51, 47-57. [CrossRef]

133. Sendra, L.; Carreño, O.; Miguel, A.; Montalvá, E.; Herrero, M.J.; Orbis, F.; Noguera, I.; Barettino, D.; López-Andújar, R.; Aliño, S.F. Low RNA translation activit limits the efficacy of hydrodynamic gene transfer to pig liver in vivo. J. Gene Med. 2014, 16, 179-192.

134. de Groot, G.H.; Reuvers, C.B.; Schalm, S.W.; Boks, A.L.; Terpstra, O.T.; Jeekel, H.; ten Kate, F.W.; Bruinvels, J. A reproducible model of acute hepatic failure by transient ischemia in the pig. J. Surg. Res. 1987, 42, 92-100. [CrossRef]

135. Zacharoulis, D.; Rountas, C.; Katsimpoulas, M.; Morianos, J.; Chatziandreou, I.; Vassilopoulos, G. Efficient liver gene transfer with foamy virus vectors. Med. Sci. Monit. Basic Res. 2013, 19, 214-220. [CrossRef]

136. Gruntman, A.M.; Flotte, T.R. Progress with Recombinant Adeno-Associated Virus Vectors for Gene Therapy of Alpha-1 Antitrypsin Deficiency. Hum. Gene Ther. Methods 2015, 26, 77-81. [CrossRef]

137. Brunetti-Pierri, N.; Ng, T.; Iannitti, D.; Cioffi, W.; Stapleton, G.; Law, M.; Breinholt, J.; Palmer, D.; Grove, N.; Rice, K. Transgene expression up to 7 years in nonhuman primates following hepatic transduction with helper-dependent adenoviral vectors. Hum. Gene Ther. 2013, 24, 761-765. [CrossRef]

138. Romero-Vásquez, F.; Chávez, M.; Pérez, M.; Arcaya, J.L.; García, A.J.; Rincón, J.; Rodríguez-Iturbe, B. Overexpression of HGF transgene attenuates renal inflammatory mediators, $\mathrm{Na}(+)$-ATPase activity and hypertension in spontaneously hypertensive rats. Biochim. Biophys. Acta 2012, 1822, 1590-1599. [CrossRef] [PubMed]

139. Corridon, P.R.; Rhodes, G.J.; Leonard, E.C.; Basile, D.P.; Gattone, V.H.; Bacallao, R.L.; Atkinson, S.J. A method to facilitate and monitor expression of exogenous genes in the rat kidney using plasmid and viral vectors. Am. J. Physiol. Renal Physiol. 2013, 304, F1217-F1229. [CrossRef]

140. De La Vega, J.; Braak, B.T.; Azzoni, A.R.; Monteiro, G.A.; Prazeres, D.M. Impact of plasmid quality on lipoplex-mediated transfection. J. Pharm. Sci. 2013, 102, 3932-3941. [CrossRef]

141. Kamimura, K.; Yokoo, T.; Abe, H.; Kobayashi, Y.; Ogawa, K.; Shinagawa, Y.; Inoue, R.; Terai, S. Image-Guided Hydrodynamic Gene Delivery: Current Status and Future Directions. Pharmaceutics 2015, 7, $213-223$. [CrossRef]

142. Konry, T.; Sarkar, S.; Sabhachandani, P.; Cohen, N. Innovative Tools and Technology for Analysis of Single Cells and Cell-Cell Interaction. Annu. Rev. Biomed. Eng. 2016, 18, 259-284. [CrossRef]

143. Beck, M.; Schmidt, A.; Malmstroem, J.; Claassen, M.; Ori, A.; Szymborska, A.; Herzog, F.; Rinner, O.; Ellenberg, J.; Aebersold, R. The quantitative proteome of a human cell line. Mol. Syst. Biol. 2011, 7, 549. [CrossRef]

144. Han, F.; Lillard, S.J. In-situ sampling and separation of RNA from individual mammalian cells. Anal. Chem. 2000, 72, 4073-4079. [CrossRef] 
145. Herrero, M.J.; Sabater, L.; Guenechea, G.; Sendra, L.; Montilla, A.I.; Abargues, R.; Navarro, V.; Aliño, S.F. DNA delivery to 'ex vivo' human liver segments. Gene Ther. 2012, 19, 504-512. [CrossRef]

146. Sendra Gisbert, L.; Miguel Matas, A.; Sabater Ortí, L.; Herrero, M.J.; Sabater Olivas, L.; Montalvá Orón, E.M.; Frasson, M.; Abargues López, R.; López-Andújar, R.; García-Granero Ximénez, E.; et al. Efficacy of hydrodynamic interleukin 10 gene transfer in human liver segments with interest in transplantation. Liver Transpl. 2017, 23, 50-62. [CrossRef]

147. Sendra, L.; Miguel, A.; Herrero, M.J.; Forteza, M.J.; Chaustre, F.L.; Noguera, I.; Diaz, A.; Bodi, V.; Alino, S.F. Human Interleukin-10 Naked DNA Delivery to Infarcted Pig Heart by Catheter Mediated Retrograde Injection in Coronary Sinus. J. Clin. Exp. Cardiol. 2014, 5, 315. [CrossRef]

148. Seldon, P.M.; Barnes, P.J.; Giembycz, M.A. Interleukin-10 does not mediate the inhibitory effect of PDE-4 inhibitors and other cAMP-elevating drugs on lipopolysaccharide-induced tumors necrosis factor-alpha generation from human peripheral blood monocytes. Cell Biochem. Biophys. 1998, 29, 179-201. [CrossRef]

149. Frasson, M.; Sendra, L.; Miguel, A.; Herrero, M.J.; Montalvá, E.; López-Andújar, R.; Martínez-Pastor, J.; Martí-Bonmatí, L.; Granero, E.G.; Aliño, S. Hydrodynamic Il10 Gene Transfer In Human Colon: Results From An "Ex-Vivo" Study With Potential Clinical Application In Crohn's Disease. Inflamm. Bowel Dis. 2017, 23, 1360-1370. [CrossRef]

150. Guillem, V.M.; Tormo, M.; Revert, F.; Benet, I.; García-Conde, J.; Crespo, A.; Aliño, S.F. Polyethyleneimine-based immunopolyplex for targeted gene transfer in human lymphoma cell lines. J. Gene Med. 2002, 4, 170-182. [CrossRef]

151. Guillem, V.M.; Tormo, M.; Moret, I.; Benet, I.; García-Conde, J.; Crespo, A.; Aliño, S.F. Targeted oligonucleotide delivery in human lymphoma cell lines using a polyethyleneimine based immunopolyplex. J. Control. Release 2002, 83, 133-146. [CrossRef]

152. Lledo, S.; Alfonso, R.; Alino, S.F. Antisense gene therapy using anti-k-ras and antitelomerase oligonucleotides in colorectal cancer. Rev. Esp. Enferm. Dig. 2005, 97, 472-480. [CrossRef]

153. Díaz-Moscoso, A.; Guilloteau, N.; Bienvenu, C.; Méndez-Ardoy, A.; Blanco, J.L.; Benito, J.M.; Le Gourriérec, L.; Di Giorgio, C.; Vierling, P.; Defaye, J. Mannosyl-coated nanocomplexes from amphiphilic cyclodextrins and pDNA for site-specific gene delivery. Biomaterials 2011, 32, 7263-7273. [CrossRef]

154. Taniyama, Y.; Azuma, J.; Kunugiza, Y.; Iekushi, K.; Rakugi, H.; Morishita, R. Therapeutic option of plasmid-DNA based gene transfer. Curr. Top. Med. Chem. 2012, 12, 1630-1637. [CrossRef]

155. Balbino, T.A.; Azzoni, A.R.; de la Torre, L.G. Microfluidic devices for continuous production of pDNA/cationic liposome complexes for gene delivery and vaccine therapy. Colloids Surf. B Biointerfaces 2013, 111, 203-210. [CrossRef]

156. Sevimli, S.; Sagnella, S.; Kavallaris, M.; Bulmus, V.; Davis, T.P. Assessment of cholesterol-derived ionic copolymers as potential vectors for gene delivery. Biomacromolecules 2013, 14, 4135-4149. [CrossRef]

157. Heller, R.; Heller, L.C. Gene electrotransfer clinical trials. Adv. Genet. 2015, 89, 235-262.

158. Mendrek, B.; Mendrek, B.; Sieroń, Ł.; Żymełka-Miara, I.; Binkiewicz, P.; Libera, M.; Smet, M.; Trzebicka, B.; Sieron, A.L.; Kowalczuk, A.; et al. Nonviral Plasmid DNA Carriers Based on N,N'-Dimethylaminoethyl Methacrylate and Di(ethylene glycol) Methyl Ether Methacrylate Star Copolymers. Biomacromolecules 2015, 16, 3275-3285. [CrossRef]

159. Zhang, Z.B.; Gao, W.; Shi, Y.; Liu, L.; Ma, N.; Chen, J.; Zhu, Z.J. Protective role of normothermic machine perfusion during reduced-size liver transplantation in pigs. Liver Transpl. 2016, 22, 968-978. [CrossRef]

(C) 2018 by the authors. Licensee MDPI, Basel, Switzerland. This article is an open access article distributed under the terms and conditions of the Creative Commons Attribution (CC BY) license (http:/ / creativecommons.org/licenses/by/4.0/). 